IZA DP No. 6784

Does It Pay for Women to Volunteer?

Robert M. Sauer

August 2012

Forschungsinstitut zur Zukunft der Arbeit Institute for the Study of Labor 


\title{
Does It Pay for Women to Volunteer?
}

\author{
Robert M. Sauer \\ University of Bristol \\ and IZA
}

\section{Discussion Paper No. 6784 \\ August 2012}

\author{
IZA
}

P.O. Box 7240

53072 Bonn

Germany

\author{
Phone: +49-228-3894-0 \\ Fax: +49-228-3894-180 \\ E-mail: iza@iza.org
}

\begin{abstract}
Any opinions expressed here are those of the author(s) and not those of IZA. Research published in this series may include views on policy, but the institute itself takes no institutional policy positions.

The Institute for the Study of Labor (IZA) in Bonn is a local and virtual international research center and a place of communication between science, politics and business. IZA is an independent nonprofit organization supported by Deutsche Post Foundation. The center is associated with the University of Bonn and offers a stimulating research environment through its international network, workshops and conferences, data service, project support, research visits and doctoral program. IZA engages in (i) original and internationally competitive research in all fields of labor economics, (ii) development of policy concepts, and (iii) dissemination of research results and concepts to the interested public.
\end{abstract}

IZA Discussion Papers often represent preliminary work and are circulated to encourage discussion. Citation of such a paper should account for its provisional character. A revised version may be available directly from the author. 
IZA Discussion Paper No. 6784

August 2012

\section{ABSTRACT}

\section{Does It Pay for Women to Volunteer?}

This paper estimates the economic and non-economic returns to volunteering for prime-aged women. A woman's decision to engage in unpaid work, and to marry and have children, is formulated as a forward-looking discrete choice dynamic programming problem. Simulated maximum likelihood estimates of the model indicate that an extra year of volunteer experience increases wage offers in part-time work by $8.3 \%$ and wage offers in full-time work by $2.4 \%$. The behavioral model also reveals an adverse selection mechanism which is consistent with the negative returns to volunteering found in reduced-form wage regressions. The negative selection is driven by differential unobserved market-productivity and heterogeneous marginal utilities of future consumption. The structural estimates also imply that the economic returns to volunteering are relatively more important than non-economic returns, and introduction of a tax-credit for volunteering-related childcare expenses would substantially increase volunteer labor supply and female lifetime earnings.

JEL Classification: $\quad \mathrm{C} 35, \mathrm{C} 53, \mathrm{C} 61, \mathrm{D} 91, \mathrm{J12}, \mathrm{J13}, \mathrm{J} 22, \mathrm{~J} 24, \mathrm{~J} 31, \mathrm{~J} 64$

Keywords: female labor supply, marriage, fertility, negative selection, attrition, dynamic programming, structural estimation, simulated maximum likelihood, volunteering

Corresponding author:

Robert M. Sauer

University of Bristol

Department of Economics

8 Woodland Road

BS8 1TN Bristol

United Kingdom

E-mail: robertmsauer@gmail.com 


\section{Introduction}

Working for no pay is a widespread economic activity that is not yet well understood. Data from the 2005 Panel Study of Income Dynamics (PSID) indicate that $32.7 \%$ of the prime-aged US population engaged in unpaid work for non-profit organizations in the preceding year. As with charitable contributions of money, a deeper understanding of charitable donations of time might help economists and policymakers anticipate behavioral responses to changes in economic fundamentals and government policy. For example, how would volunteer labor supply react to more restricted paid work opportunities in an economic downturn? Does community service work improve future labor market opportunities as is implicitly assumed in most welfare-to-work programs? How would volunteer labor supply respond to monetary incentives offered through the income tax system? Answers to these types of questions require estimates of the economic and non-economic returns influencing the decision to offer labor services for free.

Previous research on volunteer labor supply has emphasized two main motives for volunteering. The first, referred to as the consumption motive, is associated with a direct increase in contemporaneous utility that one receives from volunteering. The price of consuming (or cost of supplying) volunteer hours is the opportunity cost of time which could have been devoted to paid work or leisure. The second, referred to as the investment motive, is associated with an indirect increase in future utility. Supplying volunteer hours today may provide job contacts and raise human capital levels which increase future earnings.

In one of the first empirical studies of volunteering, Menchik and Weisbrod (1987) analyze each of these two main motives in isolation. They conclude that both motives play an important role in the decision to volunteer. The opportunity cost of time is also found to be substantial. However, Freeman (1997), which is the only other seminal empirical paper on volunteering, fails to confirm the importance of the consumption motive, and does not find a strong relationship with paid employment alternatives. ${ }^{1}$

The conclusions reached in these two leading studies, and in essentially the entire literature on volunteer labor supply, should be considered highly tentative for at least three reasons. First, previous studies do not sufficiently take into account the expected future monetary payoff to volunteer experience. This is mainly due to data limitations. The data sources often do not contain information on an individual's post-volunteer employment status or earnings. Second, earnings opportunities in paid employment options are treated as exogenous. This yields biased estimates of the opportunity cost of time. Third, the endo-

\footnotetext{
${ }^{1}$ In sharp contrast to the vast literature on the charitable giving of money (see, e.g., Becker (1974), Clotfelter (1985), Weisbrod (1998) and Andreoni (1989,1990)), the empirical literature on volunteer labor supply is extremely limited. Andreoni (2006) provides a comprehensive yet unavoidably short review.
} 
geneity of marital status and the presence of children, both key determinants of volunteering behavior, is entirely ignored.

In this paper, all three of these major problems in the volunteer labor supply literature are explicitly addressed. The decision to work for no pay is analyzed using data on female respondents in the PSID between the years 2001 and 2005. ${ }^{2}$ These data are much better suited for identifying the two volunteering motives and the opportunity cost of time. Between 2001 and 2005, the PSID collected information on volunteering for non-profit organizations, providing longitudinal data on unpaid and paid employment outcomes. Crucial for identification, the data contain individual-level transitions between unpaid and paid employment states as well as pre- and post-volunteering earnings.

The theoretical framework used to interpret the data assumes that each woman, between the ages of 25 and 55, maximizes the discounted present value of expected lifetime utility by making joint and sequential decisions on unpaid and paid employment status. It is particularly important in this context to formulate the decision problem as a dynamic program since the investment motive for volunteering is naturally forward-looking. Since wage offer functions in paid employment are estimated simultaneously with the decision to volunteer, the model also produces selection-corrected estimates of volunteer experience and the opportunity cost of time. The selection-correction uses the value functions obtained from the solution of the dynamic program together with wage offer functions that contain theoretically motivated exclusion restrictions. Similar to Keane and Wolpin (2010), the endogeneity of non-labor income and family composition are accounted for by modeling marriage and conception choices jointly with employment decisions.

The theoretical framework also nests the consumption and investment motives into one unified model, providing a new empirical strategy for directly estimating their relative importance. Relative importance estimates have not yet been provided in the literature. This is accomplished by specifying the contemporaneous utility flow in the model as CRRA in consumption with an additively separable component that captures the non-economic returns to volunteering. The economic returns to volunteering operate via wage offer functions which affect future consumption and hence the CRRA component of utility.

The dynamic programming model is solved by backward recursion, employing a novel approximate solution technique that builds on an approach suggested by Geweke and Keane (2001) and implemented by Houser (2003). The approximate solution is nested within a simulated maximum likelihood (SML) procedure that accounts for the initial conditions

\footnotetext{
${ }^{2}$ Women volunteer more often than men across all age groups, education groups, and other major demographic characteristics. According to the 2005 PSID, 35\% of female respondents volunteered during the previous year, compared to $30 \%$ of male respondents. Future work will analyze male volunteering behavior and gender differences.
} 
problem and incorporates classification error in discrete outcomes (unpaid and paid employment state, marital status and conception choice) as well as measurement error in continuous outcomes (part-time, full-time and husband wages). The SML algorithm, originally developed by Keane and Wolpin (2001), and made more general by Keane and Sauer $(2009,2010)$, is further extended in this paper by including probabilities of survey non-response in the likelihood. These latter probabilities help correct for potential biases due to non-random missingness/attrition.

The SML estimates of the model indicate that both the economic and non-economic returns to volunteering are substantial. In particular, an additional year of volunteer experience raises wage offers in part-time work by $8.3 \%$ and wage offers in full-time work by $2.4 \%$. This is in sharp contrast to reduced-form wage regressions which yield negative returns to volunteering. The estimated model also reveals an adverse selection mechanism which explains why reduced-form estimates of the returns to volunteering are downward biased.

Volunteering is optimal in the model when contemporaneous non-economic returns and expected future economic returns sufficiently outweigh the disutility of unpaid work effort and volunteering-related childcare costs. According to the structural estimates, this occurs most often amongst highly educated women who have low unobserved market-productivity. Highly educated women receive greater non-economic returns, and conditional on education, low market-productivity women benefit more from the future wage returns. This is because low market-productivity women receive lower current wage offers, have lower current consumption levels, and hence higher marginal utilities of future consumption. Differential marginal utilities of future consumption arise as a result of the estimated curvature of the CRRA component of utility. Once this negative selection mechanism is accounted for, the wage returns to volunteering become positive and substantial in magnitude.

The estimation results also imply that the economic returns to volunteering are relatively more important than the non-economic returns. That is, the investment motive outweighs the consumption motive. Relative importance is measured by comparing lifetime utility levels in simulations which sequentially introduce non-economic and economic returns into the model. The policy implications of the study are analyzed by simulating the effects of a tax credit for volunteering-related childcare costs. Introduction of a tax credit generates a $36 \%$ increase in volunteer labor supply and a 3.7\% increase in mean lifetime earnings. The increase in lifetime earnings covers more than one-third of the costs of providing tax relief.

The rest of the paper is organized as follows. The next section describes the PSID data used in estimation. Section 3 presents the model and explains the solution method. Section 4 outlines the estimation procedure and discusses identification of structural parameters. 
Section 5 highlights key parameter estimates. Section 6 explains the adverse selection mechanism in more detail, measures the relative importance of the consumption and investment motives, and analyzes the effects of introducing a tax credit for volunteering-related childcare expenses. Section 7 summarizes and enumerates several extensions of the model reserved for future research.

\section{Data}

The data are drawn from the Panel Study of Income Dynamics (PSID), including both the core random sample and the nonrandom Survey of Economic Opportunity. PSID families were re-interviewed annually from 1968 to 1997 and biennially thereafter. In 2001, the PSID introduced a new module on philanthropic activities, in which household heads and spouses were asked detailed questions about their charitable giving and volunteering activities for non-profit organizations. After the 2005 wave, the questions on charitable giving were retained but the volunteering questions were dropped, due to a lack of funding (charitable giving).

The three PSID waves between 2001 and 2005 contain a total of 7,778 female household heads or spouses. Restricting the sample to those aged 25 to 55 reduces the number of women to 4,254 . The age restriction is imposed to avoid modeling education and retirement decisions. Women aged 25 to 55 who are students, retired, disabled, or in jail at any time during the three waves are also dropped, as are those for whom it is impossible to infer education level or marital status. These latter restrictions reduce the number of women to 3,664. For computational tractability, black women are excluded from the analysis. This yields a sample of 2,479 women who responded to at least one survey wave between 2001 and $2005 .^{3}$

The PSID questionnaire explains to respondents the meaning of volunteering for a charitable organization. Charitable organizations "include religious or non-profit organizations that help those in need or that serve and support the public interest. They range in size from national organizations like the United Way and the American Red Cross down to local community organizations. They serve a variety of purposes such as religious activity, helping people in need, health care and medical research, education, arts, environment, and international aid." Volunteering is "spending time doing unpaid work and not just belonging to an organization. Volunteers are involved in many activities such as coaching, helping at school,

\footnotetext{
${ }^{3}$ Note that 89 percent of excluded cases follow from the age and race restrictions, implying that any induced sample selection biases are likely to be small. As with gender differences, race differences in volunteering behavior will be analyzed in future work.
} 
serving on committees, building and repairing, providing health care or emotional support, delivering food, doing office work, organizing activities, fund-raising, and other kinds of work done for no pay."

In the 2001 wave, respondents are asked to provide the total number of hours volunteered in the previous year, as well as the number of hours volunteered for charitable organizations that specifically help the needy. In the 2003 and 2005 waves, the volunteering questions changed. Instead of being asked directly for the total number of hours volunteered, respondents provide the number of hours volunteered in each of seven different categories of charitable organizations. The sum of hours over these seven categories is taken as the annual total.

Summary statistics on volunteer hours per week computed from the annual totals are presented in Table 1. The top panel shows that the distribution of non-zero volunteer hours in 2000 is markedly different from the distributions in 2002 and 2004 . In particular, the mean, median and standard deviation in 2000 are all considerably lower than in subsequent years. The bottom panel displays the percentage of non-zero volunteer hours donated to charitable organizations of different types. In 2000, $12.4 \%$ of total volunteer hours went to help the needy, with the rest going to all other unspecified types of organizations. Pooling over 2002 and 2004, only $4.2 \%$ of total volunteer hours went to help the needy. The rest were mainly donated to religious organizations (41\%) and organizations that aid children or youth $(35.2 \%)$.

Because of the rather clear non-comparability in the volunteering questions across years, as well as other documented problems with the hours data (see Wilhelm (2008)), only the extensive margin of volunteering is considered. A woman is classified as volunteering for the year if annual volunteer hours are greater than zero. This crude classification is consistent with the volunteering question re-introduced into the 2011 wave of the PSID, which simply asks whether the respondent volunteered in the previous year. Hours data are no longer collected.

Women are also classified into discrete paid work categories in each year depending on reported annual paid work hours and labor earnings. Therefore, the intensive margin in paid work is incorporated into the model. Part-time employment is assigned if annual paid work hours are greater than zero and less than or equal to 1750, and labor earnings are either greater than zero or missing. If annual paid work hours are greater than 1750 and labor earnings are greater than zero or missing, full-time employment is assigned. A woman is classified as non-employed for the year if she is not volunteering and not engaged in paid work.

Note that according to these assignment rules, a woman may be classified as both em- 
ployed in a paid job and volunteering in a given year. However, it is possible that some of these women are engaging in paid work and volunteering at distinct times within a year. For this reason, and other possible assignment errors related to mis-reported paid work hours, it is important to account for classification error in estimation.

Sample means and standard deviations for employment and other outcomes are displayed in column (1) of Table 2. Columns (2) and (3) split the sample by frequency of survey response. Several substantial differences between women who respond in every wave and those who do not can be discerned. Women who do not respond in every wave, constituting $14 \%$ of the sample, are much less likely to volunteer. They also work full-time more often, are more likely to be single, have fewer children, and have lower-earning husbands. These sharp differences highlight the importance of accounting for endogenous missingness/attrition in estimation.

The employment choice distribution by age range, over six mutually exclusive employment states, is shown in Table 3. The bottom row displays row percentages for the age range 25-55 and indicates that volunteering is rarely an exclusive activity. The overwhelming majority of volunteering is performed in conjunction with paid employment - $5.1 \%$ volunteer without paid work, $12 \%$ work part-time and volunteer, and $16.8 \%$ work full-time and volunteer. The choice distribution also shifts somewhat with age. In particular, the proportion in the parttime and volunteer state exhibits an inverse u-shaped pattern while the proportion in the full-time and volunteer state generally increases with age.

Table 4 reports the two-year (one-wave) transition matrix for the six employment states. The diagonal elements of the matrix range from $42.4 \%$ to $61.7 \%$, implying a high incidence of transitions. From the non-employed state, $23.5 \%$ transit to volunteer jobs, and from the volunteer only state, $40.2 \%$ transit to paid employment. The majority of transitions from the combined part-time and volunteer option are into the part-time only category. Similarly, most transitions from the combined full-time and volunteer state are into the full-time only option. Persistence is strongest in the full-time only category.

Additional features of the data are displayed in Table 5, which reports the results of reduced-form regressions. The dependent variables in columns (1) - (3) are indicators for volunteering, being married, and giving birth, respectively. Estimates of linear probability models with random effects show that the incidence of volunteering, being married and giving birth all increase with education. The propensity to volunteer and to be married increases with age at a decreasing rate, while the propensity to give birth decreases with age. The proportion volunteering and the proportion giving birth are higher when married and increase with the stock of children at a decreasing rate.

Note that the fraction of variance due to the random effect is largest in column (2), 
as there is greater persistence in marital status than in volunteering or giving birth. The relatively low persistence in volunteering is consistent with the high incidence of transitions displayed in the employment transition matrix. Giving birth has virtually no persistence after controlling for the number of children already born. Column (4) displays the results of a regression with the log of husband wage as the dependent variable. The estimated coefficients on the woman's education level are quite similar to those in Column (8) using the log of female wage as the dependent variable. The fraction of variance due to the random effect is also similar. This is suggestive of positive assortative mating.

The OLS estimates in column (5) show that mean accepted female wages rise with education level, while age has a negligible effect. Column (6) adds an indicator for having volunteered in the previous wave (2 years earlier) as a proxy for accumulated volunteer experience. The coefficient on the volunteering dummy is -.143. Column (7) adds indicators for having worked part-time and full-time in the previous wave, as proxies for accumulated paid work experience. It is possible that the negative coefficient on the volunteering dummy reflects less time spent in the paid labor market rather than a negative return to volunteering per se. However, after inclusion of paid work experience, the coefficient on lagged volunteering remains negative, -.069, and precisely estimated. Note that the coefficients on the part-time and full-time dummies are positive and have expected relative values.

Column (8) adds random effects to the regression with volunteer, part-time and full-time experience proxies. The coefficient on the volunteering dummy weakens and is less precisely estimated. However, the magnitude is still substantially negative, -.038. Negative returns to volunteer experience also hold up in a variety of different specifications, including reducedform selection-correction techniques (not reported). In stark contrast to the reduced-form results, structural estimation of the behavioral model presented below produces substantially positive returns to volunteer experience. It also reveals an explicit economic mechanism for negative selection.

\section{Model}

At the beginning of each period a woman makes three joint and sequential decisions: an employment state, a marital status and whether to conceive a child. Employment, marital and fertility decisions are taken annually between the ages of 21 and 55. Women differ at age 21 according to completed education level and unobserved productivity. Education and unobserved productivity remain constant throughout the life cycle. Although not explicitly part of the choice set, education is recognized as endogenous by allowing it to be correlated 
with unobserved productivity.

\subsection{Basic Structure}

The employment choice set a woman faces at each age $a$, denoted as $K$, contains six mutually exclusive elements: non-employed $(k=1)$, volunteer only $(k=2)$, part-time only $(k=3)$, full-time only $(k=4)$, part-time and volunteer $(k=5)$, and full-time and volunteer $(k=$ 6). A woman chooses an employment state $k \in K$ at the beginning of each age $a$. The employment choice variable, $d_{a}^{k}$, is defined such that $d_{a}^{k}=1$ if a woman chooses employment state $k$ at age $a$ and $d_{a}^{k}=0$ otherwise.

Employment choices are partially constrained. Full-time work can be chosen only if a full-time job offer is received. The probability of receiving a full-time job offer is denoted by $\pi_{j}^{f}$, where $j \in K$ is the previous period employment state. Part-time and volunteer job offers arrive with certainty.

If a full-time job offer is received, part-time and full-time wage offers, denoted by $w_{a}^{p}$ and $w_{a}^{f}$, are drawn each period from known distributions, $F^{p}\left(w_{a}^{p}\right)$ and $F^{f}\left(w_{a}^{f}\right)$. If a full-time job offer is not received then only a part-time wage offer is drawn. Accumulated volunteer, parttime and full-time experience shift the means of $F^{p}\left(w_{a}^{p}\right)$ and $F^{f}\left(w_{a}^{f}\right)$. Transitions between employment states may occur depending on both wage draws and preference shocks.

A woman may also choose to be single or married at each $a$. Marital status is denoted by $m_{a}$, where $m_{a}=1$ if a woman is married (or cohabiting) and $m_{a}=0$ if single (or divorced). Marital choices are constrained. When a woman is single, she can marry only if a marriage offer is received. The probability of receiving a marriage offer is denoted by $\pi^{m}$.

Receipt of a marriage offer is accompanied by a random draw $\mu$, from a known distribution $F^{\mu}(\mu)$, which partially determines husband earnings $w_{a}^{h}$. Accepted husband wages constitute a woman's non-labor income. If the marriage offer is accepted, $\mu$ remains fixed for the duration of the marriage. Conditional on $\mu, w_{a}^{h}$ is re-drawn each year of marriage from a known distribution $F^{h}\left(w_{a}^{h}\right)$.

While married, no alternative marriage offers can be received. Marital separation may occur as a result of unfavorable husband wage draws. New marriage offers and $\mu$ draws can once again be received after one period of separation. The restriction of no "on-the-maritaljob" search implies marriage choices take place in an environment in which being single has greater option value than being married.

A woman can also choose whether or not to conceive a child at each age $a$. A child may be conceived in any employment and marital state. The fertility choice variable is denoted 
by $b_{a}$, where $b_{a}=1$ if a child is conceived at age $a$ and $b_{a}=0$ otherwise. The fecundity of a woman is taken into account by constraining $b_{a}$ to zero for $a \geq 46$. Additional fecundity issues are ignored (e.g., probability of miscarriage). If a woman chooses to conceive at age $a$, live births occur with certainty before the beginning of period $a+1$.

The utility flow at age $a$, denoted by $U_{a}$, is specified as CRRA in consumption with several additively separable components,

$$
U_{a}=\frac{\mu_{k} C_{a}^{1-\lambda}}{1-\lambda}+\sum_{k \in K^{v}} d_{a}^{k} g_{a}+\psi_{a}^{m}+\psi_{a}^{n}+d_{a}^{1} \varepsilon_{a}^{u}
$$

where $C_{a}$ is consumption and $1-\lambda$ is the parameter of constant relative risk aversion. $\lambda$ determines the curvature of the utility function and $\mu_{k}$ shifts the marginal utility of consumption depending on employment state $k$. $\mu_{k}$ equals one when $k=1$ (non-employed) and $0<\mu_{k} \leq 1$ for $k=2, \ldots, 6$. These restrictions strengthen the interpretation of $\mu_{k}$ as the disutility of work effort (or foregone leisure). In particular, adding volunteer work to a paid job can result in a lower value of $\mu_{k}$.

The first additively separable component in (1), $g_{a}$, captures the non-economic returns to volunteering. $g_{a}$ represents the consumption motive and is referred to as the warm-glow function. $K^{v}$ is the subset of $K$ that contains the volunteering options $(k=2,5,6)$. $\psi_{a}^{m}$ is the utility of being married, $\psi_{a}^{n}$ is the utility derived from children and $\varepsilon_{a}^{u}$ is a non-employed preference shock. This specification allows the consumption of goods, warm glow, marriage and children to be partial substitutes, highlighting the endogeneity of marriage and fertility in the labor supply decision.

The budget constraint at age $a$ is specified as

$$
C_{a}=\tau^{m_{a}}\left\{b\left(d_{a}^{1}+d_{a}^{2}\right)+w_{a}^{p}\left(d_{a}^{3}+d_{a}^{5}\right)+w_{a}^{f}\left(d_{a}^{4}+d_{a}^{6}\right)+w_{a}^{h} m_{a}-c_{k}\right\}
$$

where $\tau^{m_{a}}$ is the household income sharing parameter. $\tau^{m_{a}}=1$ if $m_{a}=0$ and $0 \leq \tau^{m_{a}} \leq$ 1 if $m_{a}=1$. $\tau^{1}$ must be sufficiently high to induce high wage women to marry low wage men. The lower $\tau^{1}$ is, the higher $w_{a}^{h}$ must be to compensate, encouraging positive assortative mating.

Unobserved consumption when non-employed or in the volunteer only state is represented by $b$. Note that there is also no additional current consumption when combining work for pay with a volunteer job. Current consumption could be higher if one receives non-wage benefits from volunteering such as tickets to events or dinners, or one volunteers to help protect neighborhood property. However, this distinction is ignored since it is not identified 
in estimation.

The costs of children $c_{k}$ in (2) are shared when married and depend on employment state $k$. In particular, the costs of children can be considerably higher when working full-time, and may increase when one volunteers. Childcare costs that increase with the amount of time devoted to the labor market can underly the decision of low-wage women to be non-employed (or work part-time) while married with children. Note that it is not necessary to incorporate an explicit time constraint in the model since the number of volunteering hours observed in the data are limited. ${ }^{4}$

\subsection{Additional Parameterizations}

Additional parameterizations of the model involve more fully characterizing the part-time, full-time and husband wage offer functions, the warm-glow function, the utilities of marriage and children, the cost of children, and the joint distribution of preference and productivity shocks.

Wage offers in part-time and full-time work are specified as Mincer-style functions of general and specific skills, i.e., education, accumulated work experience, and unobserved (to the econometrician) productivity,

$$
\begin{aligned}
& \ln \left(w_{a}^{p}\right)=\beta_{0 p}+\sum_{j=1}^{2} \beta_{j p} E_{j}+\sum_{j=3}^{5} \beta_{j p} A_{j-2}+\beta_{6 p} x_{a}^{v}+\beta_{7 p} x_{a}^{p}+\beta_{8 p}\left(x_{a}^{p}\right)^{2}+\beta_{9 p} x_{a}^{f}+\varepsilon_{a}^{p} \\
& \ln \left(w_{a}^{f}\right)=\beta_{0 f}+\sum_{j=1}^{2} \beta_{j f} E_{j}+\sum_{j=3}^{5} \beta_{j f} A_{j-2}+\beta_{6 f} x_{a}^{v}+\beta_{7 f} x_{a}^{p}+\beta_{8 f} x_{a}^{f}+\beta_{9 f}\left(x_{a}^{f}\right)^{2}+\varepsilon_{a}^{f}
\end{aligned}
$$

where the $E_{j}$ 's are education level dummies (see Table 5), the $A_{j}$ 's are unobserved productivity dummies, $x_{a}^{v}$ is accumulated volunteer experience, $x_{a}^{p}$ is accumulated part-time experience, $x_{a}^{f}$ is accumulated full-time experience, and $\varepsilon_{a}^{j}, j=p, f$ are transitory productivity shocks.

Note that the wage returns to volunteering $\left(\beta_{6 p}\right.$ and $\left.\beta_{6 f}\right)$ depend only on type of job (part-time or full-time), not on observed or unobserved individual characteristics. Interactions between volunteer experience, education, and unobserved productivity are difficult to identify. Nonetheless, self-selection into volunteering can be generated even with uniform

\footnotetext{
${ }^{4}$ Job termination, marriage "layoff", volunteer job offer, and part-time job offer probabilities were included in earlier versions, but identification problems arose. Asset accumulation is also not incorporated into the model. This is common in the dynamic programming literature on female labor supply (see Eckstein and Wolpin (1989), van der Klaauw (1996), Francesconi (2002) and Keane and Wolpin (2010)).
} 
wage returns.

The laws of motion in the accumulated experience variables are

$$
\begin{aligned}
& x_{a+1}^{v}=x_{a}^{v}+d_{a}^{2}+d_{a}^{5}+d_{a}^{6} \\
& x_{a+1}^{p}=x_{a}^{p}+d_{a}^{3}+d_{a}^{5} \\
& x_{a+1}^{f}=x_{a}^{f}+d_{a}^{4}+d_{a}^{6}
\end{aligned}
$$

where volunteer experience is augmented by one for each year an individual works for no pay. Accumulated volunteer experience does not vary by paid work status in order to limit the size of the state space. Part-time (full-time) experience is also augmented by one for each year an individual engages in paid part-time (full-time) work. The initial conditions are $x_{21}^{v}=x_{21}^{p}=x_{21}^{f}=0$.

The warm glow function is specified as

$$
g_{a}=\beta_{0 g}+\sum_{j=1}^{2} \beta_{j g} E_{j}+\beta_{3 g} a+\beta_{4 g} n_{a}^{1,6}+\beta_{5 g} n_{a}^{7,18}+\varepsilon_{a}^{g}
$$

where $n_{a}^{1,6}$ is the number of children between the ages of 1 and 6 , and $n_{a}^{7,18}$ is the number of children between the ages of 7 and 18. Although there is no well-established theory of what determines preferences in this context, the non-economic returns to volunteering are likely to vary with education and age through peer and informational effects (see Freeman (1997)). Children of different ages may also shift the utility of volunteering for organizations that aid children or youth, including the educational institutions of one's own children. $\varepsilon_{a}^{g}$ is a stochastic term that captures transitory volunteer preference shocks.

The laws of motion in $n_{a}^{1,6}$ and $n_{a}^{7,18}$ are

$$
\begin{aligned}
n_{a+1}^{1,6} & =n_{a}^{1,6}+b_{a}-n_{a}^{6} \\
n_{a+1}^{7,18} & =n_{a}^{7,18}+n_{a}^{6}-n_{a}^{18}
\end{aligned}
$$

with initial conditions $n_{21}^{1,6}=n_{21}^{7,18}=0$. For purposes of normalization, children are born at the beginning of period $a+1$ at age 1 .

The husband wage offer is also specified as a Mincer-style function,

$$
\begin{aligned}
\ln \left(w_{a}^{h}\right) & =\beta_{0 h}+\sum_{j=1}^{2} \beta_{j h} E_{j}+\beta_{3 h} a+\beta_{4 h} a^{2}+\mu+\varepsilon_{a}^{h} \\
\varepsilon_{a}^{h} & =\rho \varepsilon_{a-1}^{h}+\nu_{a}
\end{aligned}
$$


where the $E_{j}$ 's and $a$ are the woman's education level and age. $\mu$ is the husband individual effect described earlier, $\nu_{a}$ is a husband transitory productivity shock, and $\rho$ is the $\operatorname{AR}(1)$ serial correlation parameter. Observed male characteristics are excluded from the model in order to economize on the state space (van der Klaauw (1996), Francesconi (2002) and Keane and Wolpin (2010)). This is justified when there is a high degree of assortative mating, which appears to be the case in the data. The complex error structure helps compensate for the absence of observed male characteristics.

The utility of marriage,

$$
\psi_{a}^{m}=\beta_{1 m} x_{a}^{m}
$$

is allowed to vary with marriage duration in order to better capture persistence in marriage and the timing of divorce. The law of motion in the duration of marriage is

$$
x_{a+1}^{m}=x_{a}^{m}+m_{a}
$$

and the initial condition is $x_{21}^{m}=0$.

The utility of children is

$$
\psi_{a}^{n}=\beta_{1 b} n_{a}+\beta_{2 b}\left(n_{a}\right)^{2}+\beta_{3 b} m_{a} n_{a}+\beta_{4 b} m_{a}\left(n_{a}\right)^{2}+\varepsilon_{a}^{n}
$$

where $n_{a}$ is the total stock of children, and $\varepsilon_{a}^{n}$ is a transitory shock to the utility of conceiving at age $a$. The quadratic specification allows for diminishing marginal utility of children, limiting total fertility in the model. The interaction with $m_{a}$ helps generate differential stocks of children by marital status, and can make divorce less likely when married with children.

The law of motion in the stock of children is

$$
n_{a+1}=n_{a}+b_{a}
$$

with initial condition $n_{21}=0$. If a woman chooses to conceive at age $a$, the number and utility of children increase at $a+1$, while pregnancy and other child "start-up" costs are incurred in period $a$. Thus, conceiving a child is modeled as a dynamic investment decision.

The cost-of-children function depends on conception choice at age $a$, employment state, and the stock of children at different ages,

$$
c_{k}= \begin{cases}\beta_{0 c} b_{a} & \text { if } n_{a}=0 \\ \beta_{0 c} b_{a}+\sum_{k \notin K^{v}} \beta_{k c} d_{a}^{k}\left(n_{a}^{1,6}+\alpha_{c} n_{a}^{7,18}\right)+\beta_{v c} \sum_{k \in K^{v}} d_{a}^{k} & \text { otherwise }\end{cases}
$$


where $\beta_{0 c}$ captures pregnancy and other child "start-up" costs and $\beta_{k c}, k \notin K^{v}$ are the per-child costs of younger children when non-employed, working part-time and working fulltime, respectively. $\alpha_{c}$ is the percentage change in the costs of older children. $\beta_{v c}$ is the extra cost per child when volunteering. The restriction that child start-up costs and volunteering childcare expenses do not vary by paid work status aids in separate identification of the cost-of-children function from other utility and budget constraint parameters.

The joint distribution of non-employed and volunteering preference shocks, and parttime and full-time productivity shocks, is assumed to be multivariate normal. That is, $\left(\varepsilon_{a}^{u}, \varepsilon_{a}^{g}, \varepsilon_{a}^{p}, \varepsilon_{a}^{f}\right) \sim N\left(0, \Sigma_{1}\right)$ where $\Sigma_{1}=L L^{\prime} . L$ is the Cholesky decomposition of the covariance matrix $\Sigma_{1}$. The Cholesky elements

$$
L=\left[\begin{array}{cccc}
l_{11} & 0 & 0 & 0 \\
l_{21} & l_{22} & 0 & 0 \\
l_{31} & l_{32} & l_{33} & 0 \\
0 & 0 & l_{43} & l_{44}
\end{array}\right]
$$

are free parameters except for the restriction $l_{41}=l_{42}=0$, which imposes a zero covariance between full-time work productivity shocks, and non-employed and volunteer preference shocks. This prevents potentially large covariances from arising and aids in identification of the full-time job offer probabilities, $\pi_{j}^{f}$, which are also tied to observed transitions into full-time employment. $\pi_{1}^{f}$ and $\pi_{3}^{f}$ are estimated with all other offer probabilities set equal to one.

For simplicity, husband productivity and conception preference shocks are assumed to be contemporaneously uncorrelated and orthogonal to $\left(\varepsilon_{a}^{u}, \varepsilon_{a}^{g}, \varepsilon_{a}^{p}, \varepsilon_{a}^{f}\right)$. Specifically, $\left(\mu, \nu_{a}, \varepsilon_{a}^{n}\right) \sim$ $N\left(0, \Sigma_{2}\right)$ where

$$
\Sigma_{2}=\left[\begin{array}{ccc}
\sigma_{\mu}^{2} & 0 & 0 \\
0 & \sigma_{\nu}^{2} & 0 \\
0 & 0 & 1
\end{array}\right] .
$$

It is important to emphasize that these additional parameterizations are motivated by interpretability, parsimony and identification (discussed further below). The full structure of the model is flexible enough to produce either positive or negative selection into volunteering.

\subsection{Solution Method}

The objective of the individual is to choose an employment state, marital status and conception outcome to maximize the expected present discounted value of remaining lifetime 
utility at each age $a$. Remaining lifetime utility, at the optimal choice combination, is

$$
V_{a}\left(\Omega_{a}\right)=\max E\left[\sum_{\tau=a}^{\bar{a}} \delta^{\tau-a} U_{\tau} \mid \Omega_{a}\right]
$$

where $V_{a}\left(\Omega_{a}\right)$ is the value function, $\Omega_{a}$ is the state space, $\delta$ is the subjective discount factor and $\bar{a}$ is the terminal age. The expectation is taken over the distribution of future preference and productivity shocks, and job and marriage opportunities.

The maximization problem in (15) can be recast as a dynamic program by writing $V_{a}\left(\Omega_{a}\right)$ as the maximum over alternative-specific value functions $V_{a}^{j}\left(\Omega_{a}\right)$, where $j \in J$ is a feasible choice combination $\left(\left\{d_{a}^{k}\right\}_{k \in K}, m_{a}, b_{a}\right)$, and $V_{a}^{j}\left(\Omega_{a}\right)$ obeys the Bellman equation. That is,

$$
\begin{aligned}
V_{a}\left(\Omega_{a}\right) & =\max _{j \in J}\left[V_{a}^{j}\left(\Omega_{a}\right)\right] \\
V_{a}^{j}\left(\Omega_{a}\right) & = \begin{cases}U_{a}^{j}+\delta E\left(V_{a+1}\left(\Omega_{a+1}\right) \mid j \in J, \Omega_{a}\right) & \text { for } a<\bar{a} \\
U_{\bar{a}}^{j} & \text { for } a=\bar{a}\end{cases}
\end{aligned}
$$

and a woman chooses the option $j$ at each age $a$ that corresponds to the maximum $V_{a}^{j}\left(\Omega_{a}\right)$

The solution is generally not analytic, but can be solved numerically. A full numerical solution requires calculating $E\left(V_{a+1}\left(\Omega_{a+1}\right) \mid j \in J, \Omega_{a}\right)$ in (16) by backward recursion for all $j$ and elements of $\Omega_{a}$. Because the state space in the model is very large, a full numerical solution is not computationally practical. Therefore, an approximate solution technique is used. In contrast to approximation techniques that deal with the curse of dimensionality by reducing the number of state space points for which $E\left(V_{a+1}\left(\Omega_{a+1}\right) \mid j \in J, \Omega_{a}\right)$ is calculated (see Keane and Wolpin (1994) and Rust (1997)), the novel approach adopted here eases the computational burden in the time dimension.

The approximate $E\left(V_{a+1}\left(\Omega_{a+1}\right) \mid j, \Omega_{a}\right)$ is calculated as follows. For any given choice $j$ at age $a$, and any given element of $\Omega_{a}$,

1. Update the deterministic part of the state space and draw a set of period $a+1$ error terms (draw $s$ ), to obtain $\Omega_{a+1}^{s}$.

2. Obtain each $V_{a+1}^{j}\left(\Omega_{a+1}^{s}\right)$, by calculating the current period returns at $a+1$ and approximating $E\left(V_{a+2}\left(\Omega_{a+2}\right) \mid j \in J_{a+1}, \Omega_{a+1}^{s}\right)$ by a reduced-form function of state space elements at $a+2$.

3. Calculate $V_{a+1}^{s}\left(\Omega_{a+1}^{s}\right)=\max _{j \in J_{a+1}}\left[V_{a+1}^{j}\left(\Omega_{a+1}^{s}\right)\right]$, taking into account job and marriage 
offer probabilities.

4. Repeat steps (1) - (3) S times, and calculate $\widehat{E}\left(V_{a+1}\left(\Omega_{a+1}\right) \mid j, \Omega_{a}\right)=\frac{1}{S} \sum_{s=1}^{S} V_{a+1}^{s}\left(\Omega_{a+1}^{s}\right)$.

Steps (1) - (4) are performed for each feasible $j$ at age $a$, and every element of $\Omega_{a}$.

The approximate $E\left(V_{a+2}\left(\Omega_{a+2}\right) \mid j \in J_{a+1}, \Omega_{a+1}^{s}\right)$ in step (2) is specified as a linear function of state space elements that have a law of motion. That is,

$$
\widehat{E}\left(V_{a+2}\left(\Omega_{a+2}\right) \mid j \in J, \Omega_{a+1}^{s}\right)=\gamma_{1} x_{a+2}^{v}+\gamma_{2} x_{a+2}^{p}+\gamma_{3} x_{a+2}^{f}+\gamma_{4} x_{a+2}^{m}+\gamma_{5} n_{a+2}
$$

where the values of the states at $a+2$ depend on $j$ at $a+1$.

The approximation technique essentially solves a sequence of two period dynamic problems by backward recursion, with an imbedded function of state space elements at $a+2$ to capture the "omitted" future beyond period $a+1$. This builds on the method proposed by Geweke and Keane (2001), and implemented by Houser (2003), by incorporating more structure of the model via a Monte Carlo integration step at $a+1$. Geweke and Keane (2001) suggest imbedding a deterministic function of state space elements directly at $a+1$, using laws of motion only to capture the forward-looking aspect of the model.

Limiting the length of the backward recursion to two periods only also makes it very easy to handle serially correlated errors (as in the husband wage offer function). Simulated shocks at age $a$ can be carried forward into the backward recursion without a need for discretizing the distribution. Note that the approximation method can also be viewed as incorporating a general form of time-inconsistent preferences into the model. This is supported by Fang and Silverman (2009) who find a high degree of short-term impatience in a dynamic programming model of female labor supply with quasi-hyperbolic time discounting. ${ }^{5}$

\section{Estimation}

The parameters of the model are estimated by simulated maximum likelihood (SML). For each trial vector of parameters, the dynamic program is solved using the approximate solution technique described above, event histories are simulated, and the likelihood function is constructed. The SML algorithm, originally developed by Keane and Wolpin (2001) and

\footnotetext{
${ }^{5} \mathrm{~A}$ full backward recursion with Monte Carlo integration took over sixteen hours to solve (on a high-end MacBook Pro). The Keane and Wolpin (1994) approximate solution technique was also attempted but the number of state space points for which $E\left(V_{a+1}\left(\Omega_{a+1}\right) \mid j \in J, \Omega_{a}\right)$ could be fully solved within a reasonable time frame was tiny. The solution method proposed here requires only 15 seconds. Future work will explore the performance of the method compared to alternatives.
} 
made more general by Keane and Sauer $(2009,2010)$, is further extended here to correct for biases due to non-random missingness/attrition.

\subsection{SML Procedure}

For a given education level and unobserved productivity type, simulated event histories are generated as follows:

1. Draw a set of preference and productivity shocks, and job and marriage offers at age $a$.

2. Draw $S$ sets of preference and productivity shocks at age $a+1$ and calculate $\widehat{E}\left(V_{a+1}\left(\Omega_{a+1}\right) \mid j, \Omega_{a}\right)$ for each feasible $j$ at age $a$.

3. Given the draws from step (1), and $\widehat{E}\left(V_{a+1}\left(\Omega_{a+1}\right) \mid j, \Omega_{a}\right)$ from step (2), calculate $V_{a}^{j}\left(\Omega_{a}\right)$ for each $j$.

4. Choose the alternative $j$ with the maximum $V_{a}^{j}\left(\Omega_{a}\right)$ and update the state space according to the laws of motion.

5. Repeat steps (1) through (4) for each age $a($ from $\underline{a}=21$ to $\bar{a}=55)$.

Steps (1) through (5) are repeated $R$ times for each education level and unobserved productivity type. ${ }^{6}$

The simulated choices generated from the above procedure serve as input into the likelihood function via joint probabilities of reported choices, conditional on simulated choices. These conditional choice probabilities can be derived from an underlying classification error process and are referred to as classification rates. By assuming independent classification errors in all discrete choices, classification rates can be constructed for each choice in isolation.

Consider first the classification rates for reported employment state. Let $d_{i a}^{*}=k, k \in K$, be the reported employment choice of woman $i$ at age $a$, and let $d_{a}^{r}=j, j \in K, r \in R$, be the $r$ th simulated employment choice. Conditional on $d_{a}^{r}$, there are six classification rates,

\footnotetext{
${ }^{6}$ There are three observed education levels and four unobserved productivity types, hence $12 * R$ simulated event histories. $R$ was set to 40 and $S$ to 20 . Further increasing $R$ and $S$ did not lead to important differences in outcomes. Three education levels were deemed sufficient from an analysis of the raw data, and more than four unobserved productivity types did not noticeably improve model fit.
} 
$\pi_{j k}^{e}=\operatorname{Pr}\left(d_{i a}^{*}=k \mid d_{a}^{r}=j\right)$, that obey the adding up constraint $\sum_{k=1}^{6} \pi_{j k}^{e}=1$. For reasons of parsimony and identification, the $6 \times 6$ matrix of employment classification rates is restricted to be

$$
\Pi^{e}=\left[\begin{array}{cccccc}
\pi_{11}^{e} & \pi_{1}^{e} & \pi_{1}^{e} & \pi_{1}^{e} & \pi_{1}^{e} & \pi_{1}^{e} \\
\pi_{2}^{e} & \pi_{11}^{e} & \pi_{2}^{e} & \pi_{2}^{e} & \pi_{25}^{e} & \pi_{2}^{e} \\
\pi_{3}^{e} & \pi_{3}^{e} & \pi_{11}^{e} & \pi_{3}^{e} & \pi_{3}^{e} & \pi_{3}^{e} \\
\pi_{4}^{e} & \pi_{4}^{e} & \pi_{25}^{e} & \pi_{11}^{e} & \pi_{4}^{e} & \pi_{4}^{e} \\
\pi_{5}^{e} & \pi_{5}^{e} & \pi_{5}^{e} & \pi_{5}^{e} & \pi_{11}^{e} & \pi_{25}^{e} \\
\pi_{6}^{e} & \pi_{6}^{e} & \pi_{6}^{e} & \pi_{6}^{e} & \pi_{65}^{e} & \pi_{11}^{e}
\end{array}\right]
$$

where $\pi_{25}^{e}$ and $\pi_{65}^{e}$ are estimated and $\pi_{11}^{e}$ is normalized to be close to one. The identification of $\pi_{25}^{e}$ and $\pi_{65}^{e}$ follow from the difficulty of the model without classification error to fit the following transitions: from volunteer only to part-time and volunteer, from part-time and volunteer to full-time and volunteer, and from full-time and volunteer to part-time and volunteer.

The classification rates for reported marital status and birth outcome are

$$
\begin{aligned}
& \pi_{10}^{m}=\operatorname{Pr}\left(m_{i a}^{*}=0 \mid m_{a}^{r}=1\right) \\
& \pi_{01}^{m}=\operatorname{Pr}\left(m_{i a}^{*}=1 \mid m_{a}^{r}=0\right) \\
& \pi_{10}^{b}=\operatorname{Pr}\left(b_{i a}^{*}=0 \mid b_{a}^{r}=1\right) \\
& \pi_{01}^{b}=\operatorname{Pr}\left(b_{i a}^{*}=1 \mid b_{a}^{r}=0\right)
\end{aligned}
$$

where $\pi_{11 a r}^{j}=1-\pi_{10 a r}^{j}$ and $\pi_{00 a r}^{j}=1-\pi_{01 a r}^{j}$ for $j=m, b$, by the adding up constraint. The marriage classification rates are estimated but the birth classification rates are fixed at levels that imply essentially no classification error. These latter probabilities are difficult to identify because of the relatively small proportion giving birth each period.

The classification rates take a logistic form which can be be derived from a classification error model with a type 1 generalized extreme value distribution. This is referred to as the biased classification error scheme in Keane and Sauer (2009, 2010). Implementing the alternative unbiased classification error scheme (Keane and Wolpin (2001)) with serially correlated errors in the model would require simulating true choice probabilities by a method such as GHK (Keane (1994)), and then embedding those true choice probabilities into classification rates. This is not necessary in the biased classification error scheme so it is computationally much less burdensome.

In order to correct for biases due to non-random missingness/attrition, the likelihood also includes non-response probabilities $\pi^{n r}$ in survey years. The non-response probability 
is specified as

$$
\pi^{n r}=\pi^{n r}\left(d_{a}^{k, r}, m_{a}^{r}, n_{a}^{1,6 r}, n_{a}^{7,18 r}, l_{i, 2003}\right)
$$

where $d_{a}^{k, r}, k \in K$, are employment choice dummies corresponding to simulated choice $d_{a}^{r}=k, m_{a}^{r}$ is simulated marital status, $n_{a}^{1,6 r}$ and $n_{a}^{7,18 r}$ are simulated fertility outcomes, and $l_{i, 2003}$ is the reported length of the interview (in minutes) in the 2003 wave. Missingness/attrition is endogenous in this specification because preference and productivity shocks, and unobserved productivity type, affect the probability of non-response through simulated choices. Note that this specification would not be computationally practical in a non-simulation based estimation procedure. The paths to the non-reported choices at age $a$ would have to be integrated out. $\pi_{a r}^{n r}$ takes a logistic form implying that the stochastic element in the non-response process is distributed type I generalized extreme value.

The length of the interview $l_{i, 2003}$ in (20) provides a source of exogenous variation which aids in identification of the non-response probability (see also Hill and Willis $(2001)$ ). $l_{i, 2003}$ is assumed to be randomly assigned after controlling for endogenous labor market, marriage and conception choices. $l_{i, 2003}$ is non-zero for individuals that answered the 2003 wave but did not respond in the 2005 wave. Length of interview information is not available for the 2001 wave.

Simulated accepted wages in part-time and full-time jobs serve as input into the likelihood function via measurement error densities. Let $w_{i a}^{*}$ be the reported accepted wage at age $a$ and $w_{a r}$ the simulated accepted wage. $w_{i a}^{*}$ is assumed to arise from the measurement error process,

$$
w_{i a}^{*}=w_{a r} \exp \left(\eta_{a}^{e, k}\right)
$$

where $\eta_{a}^{e, k}$ is a measurement error shock with variance $\sigma_{\eta^{e, k}}^{2}$ that depends on simulated employment choice $k$. Assuming $\eta_{a}^{e, k} \sim N\left(0, \sigma_{\eta^{e, k}}^{2}\right)$, the measurement error density is,

$$
f^{w}\left(w_{i a}^{*}\right)=\frac{1}{w_{i a}^{*} \sigma_{\eta^{e, k}} \sqrt{2 \pi}} \exp \left(-\frac{1}{2}\left[\frac{\ln \left(w_{i a}^{*}\right)-\ln \left(w_{a r}\right)}{\sigma_{\eta^{e, k}}}\right]^{2}\right) .
$$

To aid in identification, $\sigma_{\eta^{e, 2}}=\sigma_{\eta^{e, 1}}, \sigma_{\eta^{e, 5}}=\sigma_{\eta^{e, 3}}$, and $\sigma_{\eta^{e, 6}}=\sigma_{\eta^{e, 4}}$ are imposed in estimation. These are natural restrictions - volunteering and engaging in paid work does not influence part-time or full-time wage measurement error, and a common measurement error variance is estimated for the two unpaid employment states (non-employed and volunteer only). This latter variance becomes relevant when a wage is reported in the data, but the non-employed or volunteer only state is simulated in the model. If this occurs, $\ln \left(w_{a r}\right)$ is 
set to zero, and both the density and the likelihood become very low in value. This has the effect of encouraging new parameter configurations that lead to either a simulated paid job, or a larger $\sigma_{\eta^{e, 1}}$. Keane and Wolpin (2010) handle this type of case by shifting the mean of the wage offer distribution rather than the variance.

Simulated husband wages enter the likelihood in an analogous way. Let $h_{i a}^{*}$ be the reported accepted husband wage offer at age $a$ and $h_{a r}$ the simulated accepted husband wage offer. $h_{i a}^{*}$ is determined by,

$$
h_{i a}^{*}=h_{a r} \exp \left(\eta_{a}^{h, m_{a r}}\right)
$$

where $\eta_{a}^{h, m_{a r}}$ is a measurement error shock with variance that depends on simulated marital status $m_{a r}$. Assuming $\eta_{a}^{h, m_{a r}} \sim N\left(0, \sigma_{\eta^{h, m_{a r}}}^{2}\right)$, one obtains a measurement error density $f^{h}\left(h_{i a}^{*}\right)$ with the same form as in (22). If a husband wage is reported in the data, but the simulated marital status is single $\left(m_{a r}=0\right), \ln \left(h_{a r}\right)$ in the density is set to zero. This encourages new parameter configurations that lead to a simulated marriage $\left(m_{a r}=1\right)$, or a larger $\sigma_{\eta^{h, 0}}$.

The simulator for the likelihood contribution of woman $i$, conditional on observed education level $E_{i}$, and unobserved productivity $A_{l}$, can be written explicitly as

$$
\begin{aligned}
\hat{\ell}_{i}\left(D_{i}^{*} \mid E_{i}, A_{l}, \theta\right)= & \frac{1}{R} \sum_{r=1}^{R} \prod_{a=\tilde{a}_{i}}^{\tilde{a}_{i}+5}\left\{\sum_{j=1}^{6} \sum_{k=1}^{6} \pi_{j k}^{e} I\left[d_{a}^{r}=j, d_{i a}^{*}=k\right]\right\}^{I\left(d_{i a}^{*} \in D_{i}^{*}\right)} \\
& \times\left\{\sum_{j=0}^{1} \sum_{k=0}^{1} \pi_{j k}^{m} I\left[m_{a}^{r}=j, m_{i a}^{*}=k\right]\right\}^{I\left(m_{i a}^{*} \in D_{i}^{*}\right)} \\
& \times\left\{\sum_{j=0}^{1} \sum_{k=0}^{1} \pi_{j k}^{b} I\left[b_{a}^{r}=j, b_{i a}^{*}=k\right]\right\} \\
& \times\left\{\pi^{n r}\right\}^{I\left(N R_{i a}^{*}=1\right)}\left\{1-\pi^{n r}\right\}^{1-I\left(N R_{i a}^{*}=1\right)} \\
& \times\left\{f^{w}\left(w_{i a}^{*}\right)\right\}^{I\left(w_{i a}^{*} \in D_{i}^{*}\right)} \\
& \times\left\{f^{h}\left(h_{i a}^{*}\right)\right\}^{I\left(h_{i a}^{*} \in D_{i}^{*}\right)} \\
& \times\left\{\sum_{j=1}^{6} \pi_{j}^{f} I\left(d_{a-1}^{r}=j\right)\right\} \\
& \times\left\{\pi^{m}\right\}^{I\left(m_{a-1}^{r}=0, m_{a}^{r}=1\right)}
\end{aligned}
$$

where $D_{i}^{*}=\left\{d_{i a}^{*}, m_{i a}^{*}, b_{i a}^{*}, w_{i a}^{*}, h_{i a}^{*}\right\}_{a=\tilde{a}_{i}}^{\tilde{a}_{i}+5}$ is woman $i$ 's history of reported employment states, marital status, birth outcomes, accepted employment wage offers, and accepted hus- 
band wage offers. $\tilde{a}_{i} \geq 25$ is the age woman $i$ enters the sample. There is a maximum of five years of reported data. $\tilde{a}_{i}$ is always greater than $\underline{a}=21$, the age at which model simulation begins. This constitutes the solution to the initial conditions problem. Accumulated unpaid and paid work experience, marriage duration and the number of children at the first age for which there is a likelihood contribution are endogenously determined by the model. $\theta$ is the vector of parameters to be estimated.

The indicator functions $I\left[d_{a}^{r}=j, d_{i a}^{*}=k\right], I\left[m_{a}^{r}=j, m_{i a}^{*}=k\right]$, and $I\left[b_{a}^{r}=j, b_{i a}^{*}=k\right]$ in (24) "pick out" the appropriate classification rates depending on the reported and simulated choice combination at age $a$. The indicator functions $I\left(d_{i a}^{*} \in D_{i}^{*}\right), I\left(m_{i a}^{*} \in D_{i}^{*}\right)$, and $I\left(b_{i a}^{*} \in D_{i}^{*}\right)$ are equal to one if the corresponding choices at age $a$ are not missing in the data, and zero otherwise. Choices may be missing due to temporary exit from the sample, permanent attrition, or because it is a non-survey year.

If it is a survey year and woman $i$ did not respond, the indicator function $I\left(N R_{i a}^{*}=1\right)$ is equal to one, and zero otherwise. $I\left(N R_{i a}^{*}=1\right)$ is not uniquely determined by the values of $I\left(d_{i a}^{*} \in D_{i}^{*}\right), I\left(m_{i a}^{*} \in D_{i}^{*}\right)$, and $I\left(b_{i a}^{*} \in D_{i}^{*}\right)$ because in some cases $m_{i a}^{*}$ and/or $b_{i a}^{*}$ could be reliably backed out from the data even when not reported. This may occur in both survey and non-survey years. The functions $I\left(w_{i a}^{*} \in D_{i}^{*}\right)$ and $I\left(h_{i a}^{*} \in D_{i}^{*}\right)$ indicate whether there is a reported employment wage and reported husband wage at age $a$.

The full-time job offer probability $\pi_{j}^{f}$ enters the likelihood when $I\left(d_{a}^{r}=4,6\right)=1$, i.e., a full-time job is simulated. $I\left(d_{a-1}^{r}=j\right)$ picks out the appropriate $\pi_{j}^{f}$ depending on the simulated employment choice in the previous period. The marriage offer probability $\pi^{m}$ enters the likelihood when $I\left(m_{a-1}^{r}=0, m_{a}^{r}=1\right)=1$, i.e., a woman is simulated to be single at age $a-1$ and married at age $a$. Note that job and marriage offer probabilities appear in the likelihood according to simulated choices only.

The conditional-on-type likelihood contribution $\hat{\ell}_{i}\left(D_{i}^{*} \mid E_{i}, A_{l}, \theta\right)$ in $(24)$ is formed by averaging over $R$ simulated event histories the product over time of classification rates, measurement error densities, non-response probabilities, full-time job offer probabilities, and marriage offer probabilities, conditional on education and unobserved productivity type. The unconditional-on-type likelihood is obtained by weighting the conditional likelihood contributions by the mixing distribution.

The mixing distribution is composed of four mass point probabilities, corresponding to the four unobserved types, $A_{l}, l=0,1,2,3$. The type probabilities are

$$
\pi_{l}^{A}=\pi_{l}^{A}\left(E_{i}, C_{i}\right) \quad, l=1,2,3
$$

where $\sum_{l=0}^{3} \pi_{l}^{A}=1$. $C_{i}$ is a cohort effect defined as $\tilde{a}_{i}-25$. $C_{i}$ provides a source of 
exogenous variation to help identify the $\pi_{l}^{A}$ 's. It enters the likelihood through type probabilities only. The identifying assumption is that birth cohort partially determines unobserved productivity type, but conditional on education and productivity type, birth cohort does not influence preferences, productivity or constraints in the behavioral model. Note that type probabilities are also a function of education, recognizing the endogeneity of education, as in a correlated random effects framework. The $\pi_{l}^{A}$ 's take a multinomial logit form.

Weighting the conditional likelihood contributions in (24) by the type probabilities in (25) yields the unconditional-on-type likelihood contribution,

$$
\hat{\ell}_{i}\left(D_{i}^{*} \mid E_{i}, C_{i}, \theta\right)=\sum_{l=0}^{3} \pi_{l}^{A}\left(E_{i}, C_{i}\right) \hat{\ell}_{i}\left(D_{i}^{*} \mid E_{i}, A_{l}, \theta\right)
$$

The simulated likelihood function is $\prod_{i=1}^{N} \hat{\ell}_{i}\left(D_{i}^{*} \mid E_{i}, C_{i}, \theta\right)$, where $N$ is the number of women in the sample. Standard errors are calculated by using numerical derivatives and the outer product approximation to the Hessian.

\subsection{Identification}

In static selection models, identification of selection-corrected returns to education or experience relies heavily on exclusion restrictions (Heckman (1979) and Heckman and Honore (1990)). These are variables that enter the choice equation but not the outcome equation. In the dynamic program, the alternative-specific value functions make up the choice equation, and the wage offer function is analogous to the outcome equation. Exclusion restrictions are present because the alternative-specific value functions contain all elements of the state space, while wage offers are a function of only a subset of these elements.

Wage offer functions naturally contain a restricted set of state space elements once they are viewed as arising from a human capital production function (see Keane and Wolpin (1997)). General and specific skills such as education and work experience (both unpaid and paid) are clearly inputs to the production function. It is quite a stretch of human capital theory to consider other elements of the state space such as a woman's marital status, duration of marriage, husband productivity, and the stock of children at different ages as skill inputs. The empirical correlation between accepted wage offers and marriage and fertility outcomes more likely arises indirectly via income and substitution effects, as the model specifies, rather than directly through a production function.

Identification of the non-economic returns to volunteering also relies on exclusion restrictions. Identification requires that the warm-glow function is excluded from the current period 
returns of at least one of the alternative-specific value functions. This condition is naturally satisfied as warm glow enters the utility flows of the volunteering options only. Similarly, unobserved consumption appears only in the budget constraint of the non-employed and volunteer only options. Both unobserved consumption and warm glow are excluded from the part-time only and full-time only utility flows.

Note also that warm glow is specified as a function of education, age and the number of children at different ages, but is not directly affected by unobserved discrete types. This is because type effects were negligible in magnitude (never moving away from zero) everywhere except in the part-time and full-time wage offer functions. Identification of type effects in the warm glow function or elsewhere was possible only if types were excluded from the wage offer functions. But given the long tradition of correcting for biases due to unobserved ability/productivity in wage functions, it would not seem reasonable to exclude unobserved types from these latter equations.

It is also important to note that the CRRA parameter is identified even without data on assets. Transitions between part-time and full-time work (accepted wage variation), marital status changes (non-labor income variation) and the birth of children imply shifts in consumption levels that can smoothed over time. Birth spacing also plays a role in identifying the CRRA parameter (as well as childcare costs of older children) because it can be optimal from a lifetime consumption perspective to have children in different age groups. The implications of birth spacing for the CRRA parameter, and hence unpaid and paid employment decisions, is an additional reason why it is important to include fertility choices in the labor supply model.

Identification can also be understood via a simple analogy to the method of moments (see Diermeier, Keane and Merlo (2005)). The parameters of the female wage offer functions are tightly tied to the observed wage data and the employment choice distribution. The parameters of the husband wage offer function, also selection-corrected, are similarly tied to the observed husband wage data and marriage choices. Unobserved consumption, warm glow, the costs of children, the utility function parameters $\left(\mu_{k}, \lambda, \psi^{m}\right.$, and $\left.\psi^{n}\right)$, job and marriage offer probabilities, the reduced-form Emax function, and the extent of income sharing are free parameters that are driven by a very large number of conditional choice frequencies. The conditional choice frequencies that these parameters attempt to fit include the employment choice distribution, employment transition probabilities, marriage durations, birth frequencies and spacing, and correlations between these frequencies. Considering the very large ratio of moments to parameters, the non-wage parameters in the model are likely to be considerably over-identified. ${ }^{7}$

\footnotetext{
${ }^{7}$ Parametric distributions on wage offers also help to identify job and marriage offer probabilities (see Flinn
} 


\section{Estimation Results}

Since there are 98 estimated parameters, only point estimates of particular interest will be discussed. All parameter estimates and asymptotic standard errors appear in Tables 6 through 8. To assess model fit, outcomes simulated at the SML estimates are compared to outcomes reported in the data. Simulated outcomes are adjusted to take into account estimated classification and measurement error.

\subsection{Parameter Estimates}

The parameters of the wage offer functions show that part-time and full-time wage offers increase sharply with education level and differ substantially by unobserved productivity type. Type 1 women are the least productive in both part-time and full-time jobs, but have a comparative advantage in part-time work. Type 3 women are the most productive in both part-time and full-time jobs, and have a comparative advantage in full-time work. Overall, low productivity women constitute $13 \%$ of the population and high productivity women account for $22 \%$. The proportion of low productivity women is higher amongst older birth cohorts. Controlling for birth cohort, education does not have a significant effect on the mixing distribution.

In contrast to the negative returns to volunteer experience found in reduced-form wage regressions, the estimated wage offer functions reveal positive returns in both part-time and full-time jobs. Each year of volunteer experience increases wage offers in part-time work by $8.3 \%$ and wage offers in full-time work by $2.4 \%$. These returns are especially substantial considering the relatively small number of hours per week devoted to volunteering.

There are essentially no other estimates in the literature to which these volunteer wage offer returns can be directly compared. Day and Devlin (1998) is the most notable prior study that estimates wage returns to volunteering. Cross-sectional Canadian data is used and volunteer experience is measured by a dummy for having volunteered during the survey year. Selection and other endogeneity problems are not addressed. The overall returns to volunteering are estimated to be $6.6 \%$, but highly negative returns are found when distinguishing between types of volunteering. In particular, the returns to volunteering for a religious organization is a precisely estimated -17.8\%. As noted earlier, $41 \%$ of volunteer hours in the PSID are donated to religious organizations.

and Heckman (1982)). Although the discount factor is separately identified (Wolpin (1987) and Magnac and Thesmar (2002)), it is fixed at 0.95. Several other important identification considerations were mentioned earlier (e.g., exogenous variation in the non-response probabilities and the mixing distribution.) 
In addition to considerable economic returns to volunteering captured through higher part-time and full-time wage offers, volunteer experience raises the probability of being offered a full-time job. The full-time job offer probability is estimated to be .93 from the non-employed state, and .95 from the part-time only state. Since the probability of being offered a full-time job from any volunteering state is normalized to one, these estimates imply that the offer probability increases by 7 percentage points when volunteering is the sole work activity, and by 5 percentage points when volunteering is combined with part-time paid work.

The wage offer returns to volunteer experience imply substantial investment value, but volunteering also increases the disutility of work effort. The disutility estimates indicate that full-time work is more costly than part-time work, and volunteering adds disutility when it is combined with either of these paid work options. The estimated disutility of working in the volunteer only state is not significantly different from the disutility of working part-time only.

An additional important factor affecting the investment motive for volunteering is the curvature of the CRRA component of utility. The CRRA parameter estimate is .273. This is within the range of estimates recently produced by dynamic programming models of labor supply that explicitly incorporate data on assets. For example, Imai and Keane (2004), Van der Klaauw and Wolpin (2008), and Keane and Wolpin (2001) obtain estimates of .26, .40 and .52 , respectively. A parameter value of .273 implies a generally higher willingness to substitute consumption inter-temporally than what is often found in the life cycle consumption literature with non-separable labor supply (see Attanasio and Weber (1995), Low, Meghir and Pistaferri (2010) and Keane, Todd and Wolpin (2010)).

Turning to the consumption motive, the structural estimates reveal that the non-economic returns to volunteering increase sharply with education but do not vary much with age. Compared to women with no children, women with young children dislike volunteering, while women with older children receive considerably more warm glow. This pattern is suggestive of a substitutability between "informal volunteering" to raise one's own young children and formal volunteering for charitable organizations. Note that the estimated consumption motive corresponds to an intrinsic motivation that is net of the extrinsic motivation associated with wage returns (see Benabou and Tirole (2003)). Estimating non-economic returns also helps ensure that the wage returns to volunteering will not be upward biased.

Estimates directly related to the marriage decision indicate that husband wage offers increase with a woman's education level and are quadratic in her age. The AR(1) parameter estimate of .414 implies that serial correlation accounts for $17.4 \%$ of total idiosyncratic variance in non-labor income. Idiosyncratic variance constitutes $12.4 \%$ of total variance, 
with the remainder due to the husband individual effect. The probability of receiving a marriage offer is .089, the income sharing parameter is .551, and the utility of marriage decreases with its duration. Keane and Wolpin (2010) find a nearly identical estimate of the sharing parameter $(54.6 \%)$.

The estimated cost-of-children function shows that childcare costs increase with the amount of time devoted to the labor market. The per-child costs of children younger than 7 are $\$ 19,912, \$ 21,882$, and $\$ 26,819$ when non-employed, working part-time and working full-time, respectively. Children between the ages of 7 and 18 cost $44.6 \%$ more than younger children in each labor market state. Child start-up costs are estimated to be $\$ 29,071$, and the additional childcare costs when volunteering are $\$ 5,106$ per-child. The child startup cost is comparable to the monetary equivalent of the disutility of pregnancy estimated in Keane and Wolpin (2010).

Ignoring start-up costs and discounting, the cost function estimates imply a lower bound for the total costs of raising a child through age 18 equal to $\$ 519,164$ (in 2010 dollars). This assumes a woman is always non-employed. Assuming a woman always works full-time produces an upper bound estimate of $\$ 699,250$. The lower bound of $\$ 519,164$ is considerably higher than the upper bound of $\$ 322,560$ estimated by the U.S. Department of Agriculture (USDA), using the Consumer Expenditure Survey. The USDA cost estimates are widely believed to be considerably downward biased (see Lind (2010)). ${ }^{8}$

\section{$5.2 \quad$ Model Fit}

A comparison of the actual and simulated employment choice distribution is shown in Table 9. The bottom row, which reports row percentages over the age range 25-55, illustrates that the model fits the choice distribution very well. There is only a small over-prediction in the full-time and volunteer state. The patterns by age are also generally reproduced. In particular, the model captures the rise and subsequent decline in the proportion in the part-time and volunteer state. The model's explanation for why this pattern emerges will be discussed in the next section.

Table 10 displays the actual and predicted two-period (one-wave) employment transition matrices. Transitions out of the non-employed state are reproduced quite accurately, as are the key transitions from volunteer only to part-time and volunteer, and from part-time and volunteer to both part-time only and full-time only. There are slightly too many transitions

\footnotetext{
${ }^{8}$ Estimates not discussed for the sake of brevity include unobserved consumption when non-employed and in the volunteer only state, the utility of children, the Cholesky elements, the reduced-form Emax function, classification rates, measurement error variances and the probabilities of non-response.
} 
into the full-time and volunteer state which is consistent with the over-prediction in the choice distribution.

The ability of the model to fit marriage, birth and accepted wage outcomes is shown in Table 11. The actual and simulated proportions in the married state are quite close, but there are slightly too many underlying marriages and divorces. The predicted proportion giving birth is very close to the actual proportion, even when splitting birth outcomes by marital status. The deviations between actual and predicted accepted wages are negligible except for the predicted part-time wage which is too high.

Table 11 also reports the actual and predicted distribution of volunteer experience. The fit to the proportions with 1,2 and 3 years of experience is good, but the model has difficulty fitting the proportions with 0,4 and 5 years of experience. However, the drop in the proportions with 4 and 5 years of experience is reproduced. The model's explanation for why the tail of the distribution falls off sharply will be discussed in the next section. ${ }^{9}$

\section{Discussion}

\subsection{Negative Selection into Volunteering}

The estimated behavioral model reveals a negative selection mechanism that is capable of explaining why reduced form estimates of the wage returns to volunteering are downward biased. Volunteering is optimal in the model when the contemporaneous non-economic returns and the expected future economic returns sufficiently outweigh the disutility of unpaid work effort and volunteering-related childcare costs. According to the structural estimates, this occurs most often amongst highly educated women who have low unobserved marketproductivity.

Highly educated women tend to volunteer more often because non-economic returns increase with education level. Conditional on education, low market-productivity women benefit more from the future wage returns to volunteering. This is because low marketproductivity women receive lower current wage offers, have lower current consumption levels, and hence higher marginal utilities of future consumption. Differential marginal utilities of future consumption arise as a result of the estimated curvature of the CRRA component of utility. Once this negative selection on unobserved market-productivity is accounted for, the wage returns to volunteering become positive and substantial in magnitude.

It is important to emphasize that both differential unobserved productivity and curvature

\footnotetext{
${ }^{9}$ More powerful approaches to model validation, such as those pursued by Todd and Wolpin (2006), Keane and Wolpin (2007), and Arcidiacono, Sieg and Sloan (2007), are difficult to implement in the current context.
} 
of the utility function are necessary to generate negative selection. Had the estimated model produced a substantially higher CRRA parameter, negative selection on market-productivity type would not have arisen. For example, if the utility flow were linear, the marginal utilities of future consumption would be uniform for all productivity types (as are the wage offer returns) and selection into volunteering would be driven solely by the positive relationship between education and unobserved non-economic returns.

Note that negative selection could have been generated even in a linear utility context if low-productivity women had differentially higher wage offer returns to volunteering. However, as mentioned earlier, differential wage returns by productivity type (random coefficients) are not identified. The CRRA parameter is easier to identify because it is a direct function of more moments in the data (e.g., birth spacing) than are wage offer functions alone.

In order to illustrate the negative selection on unobserved productivity, columns (1)-(2) of Table 12 present the results of reduced-form volunteering regressions using data simulated from the model. The regressions include the same basic variables as those run on the actual data. However, since the data are simulated, unobserved market-productivity type can be included as well. The results clearly show that the propensity to volunteer increases with education and decreases with productivity type, conditional on education. That is, type 1 women (the least productive) are the most likely to volunteer, and type 3 women (the most productive) are the least likely to volunteer. The education and productivity effects hold up to additional controls related to simulated marriage and fertility outcomes.

Columns (3)-(4) present the results of reduced-form wage regressions using the simulated data. Except for the addition of unobserved productivity type, the specification is the same as in the regressions using the actual data. The regressions produce positive wage returns with or without controls for paid work experience (3.1\% and $2.9 \%$, respectively). Thus, the behavioral model of selection generates positive and substantial returns to volunteering in both structural wage offer functions and reduced-form accepted wage regressions.

The negative selection mechanism revealed by the model also helps explain the observed inverse $\mathrm{u}$-shaped age pattern in the part-time and volunteer state, and the drop off in the distribution of volunteer experience. As low market-productivity types enter the part-time and volunteer state, volunteer experience is accumulated, wage offers in both part-time and full-time work increase, consumption levels increase, and the marginal utility of future consumption falls sharply. The volunteering decision amongst low-productivity types effectively converges to that of high-productivity types, whereby volunteering is mostly driven by noneconomic returns, which depend strongly on education level and the age of children. 


\subsection{Relative Importance of Economic and Non-economic Returns}

Both the consumption and investment motives play an important role in the volunteering decision, but which motive is relatively more important in the decision to offer labor services for free? In order to address this question, the model is simulated shutting down the noneconomic and economic returns to volunteering. Non-economic returns and economic returns are then re-introduced into the model sequentially.

Columns (1)-(3) of Table 13 report the results of the simulation exercise. The total proportion choosing to volunteer goes from zero to $27.8 \%$ when non-economic returns are introduced. The proportion increases to $30.3 \%$ when economic returns are added. Although the total proportion only slightly increases with the addition of economic returns, the distribution across volunteering options significantly changes.

With only non-economic returns, nearly all volunteering is in the volunteer only and fulltime and volunteer states. It is mainly intermediate-productivity women (types 0 and 2) who volunteer in these latter states. With the addition of economic returns, the proportion in the volunteer only state falls by more than half and the proportion in the part-time and volunteer state increases sharply. It is mainly low-productivity women (type 1) who volunteer in this latter state as mentioned earlier. The implication is that economic returns are relatively more important for low-productivity women and non-economic returns are relatively more important for higher-productivity types.

By examining changes in lifetime utility, one can go further and conclude that that economic returns are relatively more important than the non-economic returns. With the introduction of non-economic returns, lifetime utility increases from 1852.46 to 1860.65. When economic returns are added, lifetime utility further increases to 1898.70. Thus, economic returns account for $82.3 \%$ of the total increase. The economic benefit to low-productivity women drives the rise in mean lifetime utility. ${ }^{10}$

\subsection{Income Tax Policy}

Charitable time donations and charitable money donations are not treated symmetrically in the US tax code. For itemizers, monetary donations are tax-deductible at the highest marginal tax rate. The tax-deductibility of monetary donations reduces the cost of giving money and encourages philanthropic activity of this type (see Auten, Sieg and Clot-

\footnotetext{
${ }^{10}$ In the context of charitable monetary donations, Sieg and Zhang (2011) measure the relative importance of private benefits (e.g., invitations to dinner parties) and warm glow. They find that private benefits are relatively more important in determining donations in the majority of organizations that offer such benefits.
} 
felter (2002)). Volunteering is not directly encouraged in a similar way. For example, the US Internal Revenue Service (IRS) permits a tax credit to be received for childcare expenses if the purpose of the expense is to allow one to work. However, the IRS explicitly states that the tax credit cannot be received if one is engaged in unpaid volunteer work (www.irs.gov/publications/p503/).

Column (4) of Table 13 reports the results of a simulation which sets the additional cost of childcare to zero when one volunteers. This corresponds to permitting a tax credit to be received for unpaid volunteer work. The tax credit generates a $36 \%$ increase in total volunteer labor supply. The proportion non-employed substantially decreases and the proportion of women choosing to work part-time rises. The increase in unpaid and paid work leads to 4.5\% higher mean accepted wages and 3.7\% higher mean lifetime earnings.

Note that the increase in mean lifetime earnings $(\$ 10,756$ per woman) covers a nonnegligible proportion $(36 \%)$ of the mean lifetime "social" cost of providing tax-relief $(\$ 29,500$ per woman). Social cost is defined as a subsidy equivalent, in which $100 \%$ of volunteeringrelated childcare costs $(\$ 5,106$ per-child) enter a discounted sum each period a woman volunteers. Of course, there are likely to be many other social benefits (e.g., poverty reduction and increased human capital of children) deriving from more volunteering in society. These latter social benefits are not taken into account in this simple cost-benefit calculation, nor are any general equilibrium effects of the tax credit policy.

\section{Conclusion}

Volunteering is both an economic and non-economic activity that has not been extensively studied by economists. In this paper, the economic and non-economic returns to volunteering are estimated using data on female respondents in the PSID. The behavioral model assumes that a woman maximizes the discounted present value of expected lifetime utility by making joint and sequential decisions on unpaid and paid work, marital status and the conception of children.

The contemporaneous utility flow in the model is specified as CRRA in consumption with an additively separable component that captures the non-economic returns to volunteering. This specification nests the investment and consumption motives for volunteering into one unified model, providing a new empirical strategy for directly estimating their relative importance.

The dynamic programming model is solved using a novel approximate solution technique, and the structural parameters are estimated by an SML procedure that is extended to adjust 
for biases due to non-random missingness/attrition. The SML estimates indicate that both the economic and non-economic returns to volunteering are substantial. In particular, an additional year of volunteer experience raises future wage offers in part-time work by $8.3 \%$ and future wage offers in full-time work by $2.4 \%$.

The behavioral model also reveals an adverse selection mechanism that is consistent with the negative returns to volunteering found in reduced-form wage regressions. According to the structural estimates, highly-educated women with low unobserved market-productivity volunteer most often. This is because non-economic returns increase with education, and conditional on education, low productivity women benefit more from the future wage returns. Low productivity women benefit more from the economic returns because they have higher marginal utilities of future consumption. Differential marginal utilities of future consumption arise from the estimated curvature of the CRRA component of utility.

A simulation exercise that sequentially introduces non-economic and economic returns into the model, suggests that the economic returns to volunteering are relatively more important than the non-economic returns. That is, the investment motive outweighs the consumption motive. The policy implications of the model are analyzed by simulating the introduction of a tax credit for volunteering-related childcare expenses. The tax credit produces a 36\% increase in volunteer labor supply and a 3.7\% increase in mean lifetime earnings. The increase in lifetime earnings covers more than one-third of the costs of providing tax relief.

Future research could expand the model in several ways. First, heterogeneity in the returns to volunteering depending on type of organization could be analyzed. Second, asset accumulation could be incorporated into the model. This could potentially change the CRRA estimate, the extent of negative selection, and the relative importance of the consumption and investment motives. Third, charitable monetary donations could be introduced. Money and time donations may be either substitutes or complements, implying that tax relief on time donations could affect monetary donations as well (see Brown and Lankford (1992), Duncan (1999), Andreoni, Gale, Scholz and Straub (2004) and Feldman (2010)). Fourth, a more explicit household decision making model could be formulated, rather than treating male labor supply as exogenous. Incorporating extensions along these lines would be interesting, but would also entail non-trivial increases in computational burden. 


\section{References}

[1] Andreoni, James. "Giving with Impure Altruism: Applications to Charity and Ricardian Equivalence," Journal of Political Economy, 97 (December 1989): 1447-1458.

[2] Andreoni, James. "Impure Altruism and Donations to Public Goods: A Theory of Warm-Glow Giving," Economic Journal, 100 (June 1990): 464-477.

[3] Andreoni, James., Gale, William G., Scholz, John K., and Straub, John. "Charitable Contributions of Time and Money," unpublished manuscript, University of Wisconsin, 2004.

[4] Andreoni, James. "Philanthropy," in S.C. Kolme and J.M. Ythier, eds., Handbook of the Economics of Giving, Altruism and Reciprocity, Volume 2, (Amsterdam: Elsevier Science Publisher B.V., 2006): 1201-1269.

[5] Arcidiacono, Peter., Sieg, Holger, and Sloan, Frank. "Living Rationally Under the Volcano? Heavy Drinking and Smoking Among the Elderly," International Economic Review, 48 (February 2007): 37-65.

[6] Attanasio, Orazio, and Weber, Guglielmo. "Is Consumption Growth Consistent with Intertemporal Optimization? Evidence from the Consumer Expenditure Survey," Journal of Political Economy, 103 (December 1995): 1121-1157.

[7] Auten, Gerald E., Sieg, Holger, and Clotfelter, Charles T. "Charitable Giving, Income and Taxes: An Analysis of Panel Data," American Economic Review, 92 (March 2002): 371-382.

[8] Becker, Gary S. "A Theory of Social Interactions," Journal of Political Economy, 82 (December 1974): 1063-1093.

[9] Benabou, R., and Tirole J., "Intrinsic and Extrinsic Motivation," Review of Economic Studies, 70 (July 2003): 489-520.

[10] Brown, E., and Lankford H., "Gifts of Money and Gifts of Time: Estimating the Effects of Tax Prices and Available Time," Journal of Public Economics, 47 (April 1992): 321-341.

[11] Clotfelter, Charles T. Federal Tax Policy and Charitable Giving, (Chicago: University of Chicago Press, 1985).

[12] Day, Kathleen M., and Devlin, Rose A. "The Payoff to Work without Pay: Volunteer Work as an Investment in Human Capital," Canadian Journal of Economics, 31 (November 1998): 1179-1191.

[13] Diermeier, Daniel, Keane, Michael P., and Merlo, Antonio. "A Political Economy Model of Congressional Careers," American Economic Review, 95, (March 2005): $347-373$. 
[14] Duncan, B. "Modeling Charitable Contributions of Time and Money," Journal of Public Economics, 72 (May 1999): 213-242.

[15] Eckstein, Zvi, and Wolpin, Kenneth I. "Dynamic Labor Force Participation of Married Women and Endogenous Wage Growth," Review of Economic Studies, (July 1989): 375-390.

[16] Fang, Hanming, and Dan Silverman. "Time-Inconsistency and Welfare Program Participation: Evidence from the NLSY," International Economic Review, 50 (November 2009): 1043-1077.

[17] Feldman, Naomi E. "Time is Money: Choosing Between Charitable Activities," American Economic Journal: Economic Policy, 2 (February 2010): 103-130.

[18] Flinn, Christopher J., and Heckman, James J. "New Methods for Analyzing Structural Models of Labor Force Dynamics," Journal of Econometrics, 18 (January 1982): 115-168.

[19] Francesconi, Marco. "A Joint Dynamic Model of Fertility and Work of Married Women," Journal of Labor Economics, 20 (Part 2): 336-380.

[20] Freeman, Richard B. "Working for Nothing: The Supply of Volunteer Labor," Journal of Labor Economics, 15 (January 1997): 140-166.

[21] Heckman, James J. "Sample Selection Bias as a Specification Error," Econometrica, 47 (January 1979): 153-161.

[22] Heckman, James J., and Honore, Bo E. "The Empirical Content of the Roy Model," Econometrica, 58 (September 1990): 1121-1149.

[23] Hill, Daniel, H. and Willis, Robert J. "Reducing Panel Attrition: A Search for Effective Policy Instruments," Journal of Human Resources, 36 (Summer 2001): 416-438.

[24] Houser, Daniel. "Bayesian Analysis of a Dynamic Stochastic Model of Labor Supply and Saving," Journal of Econometrics, 113, (April 2003): 289-335.

[25] Imai, Susumu and Keane, Michael P. "Intertemporal Labor Supply and Human Capital Accumulation," International Economic Review, (May 2004): 601-641.

[26] Keane, Michael P. "A Computationally Practical Simulation Estimator for Panel Data," Econometrica, 62 (January 1994): 95-116.

[27] Keane, Michael P., and Geweke, John. "Computationally Intensive Methods for Integration in Econometrics," in J. Heckman and E. Leamer, eds., Handbook of Econometrics, Volume 5, (Amsterdam: North Holland, 2001): 3463-3568.

[28] Keane, Michael P., and Sauer, Robert M. "Classification Error in Dynamic Discrete Choice Models: Implications for Female Labor Supply Behavior," Econometrica, 77 (May 2009): 975-991. 
[29] Keane, Michael P., and Sauer, Robert M. "A Computationally Practical Simulation Estimation Algorithm For Dynamic Panel Data Models with Unobserved Endogenous State Variables," International Economic Review, 51 (November 2010): 925-958.

[30] Keane, Michael P., Todd, Petra E., and Wolpin, Kenneth I. "The Structural Estimation of Behavioral Models: Discrete Choice Dynamic Programming Methods and Applications," in O. Ashenfelter and D. Card eds, Handbook of Labor Economics, Volume 4A, (Amsterdam: North Holland, 2010): 331-461.

[31] Keane, Michael P., and Wolpin, Kenneth I. "The Solution and Estimation of Discrete Choice Dynamic Programming Models by Simulation and Interpolation: Monte Carlo Evidence," Review of Economics and Statistics, 76, (November 1994): 648-672.

[32] Keane, Michael P., and Wolpin, Kenneth I. "The Career Decisions of Young Men," Journal of Political Economy, 105 (June 1997): 473-522.

[33] Keane, Michael P., and Wolpin, Kenneth I. "The Effect of Parental Transfers and Borrowing Constraints on Educational Attainment," International Economic Review, 42 (November 2001): 1051-1103.

[34] Keane, Michael P., and Wolpin, Kenneth I. "Exploring the Usefulness of a Non-Random Holdout Sample for Model Validation: Welfare Effects on Female Behavior," International Economic Review, 48 (November 2007): 1351-1378.

[35] Keane, Michael P., and Wolpin, Kenneth I. "The Role of Labor and Marriage Markets, Preference Heterogeneity, and the Welfare System in the Life Cycle Decisions of Black, Hispanic and White Women," International Economic Review, 51, (August 2010): 851-892.

[36] Lind, Mark. "Expenditure on Children by Families, 2010," U.S. Department of Agriculture, Center for Nutrition Policy and Promotion. Miscellaneous Publication No. 1528-2010.

[37] Low, Hamish, Meghir, Costas, and Pistaferri, Luigi. "Wage Risk and Employment Risk over the Life Cycle," American Economic Review, 100, (September 2010): 1432-1467.

[38] Magnac, T., and Thesmar, D. "Identifying Dynamic Discrete Decision Processes," Econometrica, 70 (March 2002): 801-816.

[39] Menchik, Paul L., and Weisbrod, Burton A. "Volunteer Labor Supply," Journal of Public Economics, 32 (March 1987): 159-183.

[40] Rust, John. "Using Randomization to Break the Curse of Dimensionality," Econometrica, 65 (May 1997): 487-516. 
[41] Sieg, Holger, and Zhang, Jipeng. "The Effectiveness of Private Benefits in Fundraising," International Economic Review, (2011): forthcoming.

[42] Todd, Petra, and Wolpin, Kenneth I. "Assessing the Impact of a School Subsidy Program in Mexico: Using Experimental Data to Validate a Dynamic Behavioral Model of Child Schooling and Fertility," American Economic Review, 96 (December 2006): 1384-1417.

[43] Van der Klaauw, Wilbert. "Female Labour Supply and Marital Status Decisions: A Life Cycle Model," Review of Economic Studies, 63 (April 1996): 199-235.

[44] Van der Klaauw, Wilbert, and Wolpin, Kenneth I. "Social Security and the Retirement and Savings Behavior of Low Income Households" Journal of Econometrics, (July 2008): 21-42.

[45] Weisbrod, Burton A. The Nonprofit Economy, (Cambridge: Harvard University Press 1998).

[46] Wilhelm, Mark, O. "The 2005 Center on Philanthropy Panel Study User's Guide," unpublished manuscript, Indiana University, 2008.

[47] Wolpin, Kenneth I. "Estimating a Structural Search Model: The Transition from School to Work," Econometrica, 55 (July 1987): 801-817. 
Table 1: Weekly Volunteer Hours

\begin{tabular}{|c|c|c|c|c|c|c|c|c|}
\hline Year & $\begin{array}{c}\text { \% Volunteer } \\
(\text { Hours }>0)\end{array}$ & Mean & $\begin{array}{l}\text { Standard } \\
\text { Deviation }\end{array}$ & 10 & 25 & $\begin{array}{c}\text { ercentile } \\
50\end{array}$ & 75 & 90 \\
\hline 2000 & 29.5 & 2.17 & 3.75 & .29 & 48 & .96 & 1.92 & 4.81 \\
\hline 2002 & 30.4 & 4.04 & 8.63 & .19 & .58 & 1.58 & 4.23 & 8.06 \\
\hline 2004 & 34.7 & 3.49 & 7.41 & .23 & .58 & 1.73 & 3.69 & 7.31 \\
\hline Year & $\begin{array}{l}\text { Helping } \\
\text { the } \\
\text { Needy }\end{array}$ & Religious & $\begin{array}{c}\text { Children } \\
\text { or } \\
\text { Youth }\end{array}$ & $\begin{array}{l}\text { Poor } \\
\text { Health }\end{array}$ & $\begin{array}{c}\text { Senior } \\
\text { Citizens }\end{array}$ & $\begin{array}{l}\text { Social } \\
\text { Change }\end{array}$ & Other & Total \\
\hline 2000 & .124 & - & - & - & - & - & .876 & 1.00 \\
\hline $\begin{array}{l}2002- \\
2004\end{array}$ & .042 & .410 & .352 & .044 & .037 & .032 & .083 & 1.00 \\
\hline
\end{tabular}

Note: The distributions in the top panel are for non-zero weekly volunteer hours, computed from annual totals. The bottom panel contains row percentages for non-zero hours. 
Table 2: Sample Means by Frequency of Survey Response

\begin{tabular}{|c|c|c|c|}
\hline & $\begin{array}{c}\text { Full } \\
\text { Sample } \\
(1) \\
\end{array}$ & $\begin{array}{c}\text { Respond } \\
3 \text { Waves } \\
(2)\end{array}$ & $\begin{array}{c}\text { Respond } \\
<3 \text { Waves } \\
(3)\end{array}$ \\
\hline Volunteer & $\begin{array}{l}.338 \\
(.473)\end{array}$ & $\begin{array}{c}.350 \\
(.477)\end{array}$ & $\begin{array}{l}.200 \\
(.401)\end{array}$ \\
\hline Non-employed & $\begin{array}{l}.101 \\
(.301)\end{array}$ & $\begin{array}{l}.099 \\
(.298)\end{array}$ & $\begin{array}{c}.122 \\
(.328)\end{array}$ \\
\hline Part-time & $\begin{array}{l}.318 \\
(.466)\end{array}$ & $\begin{array}{c}.321 \\
(.467)\end{array}$ & $\begin{array}{c}.273 \\
(.446)\end{array}$ \\
\hline Full-time & $\begin{array}{c}.531 \\
(.499)\end{array}$ & $\begin{array}{c}.526 \\
(.499)\end{array}$ & $\begin{array}{c}.586 \\
(.493)\end{array}$ \\
\hline Married & $\begin{array}{c}.748 \\
(.434)\end{array}$ & $\begin{array}{c}.796 \\
(.403)\end{array}$ & $\begin{array}{c}.459 \\
(.498)\end{array}$ \\
\hline Children & $\begin{array}{c}1.82 \\
(1.31)\end{array}$ & $\begin{array}{c}1.86 \\
(1.27)\end{array}$ & $\begin{array}{c}1.57 \\
(1.49)\end{array}$ \\
\hline Female Wage & $\begin{array}{c}29.43 \\
(25.78)\end{array}$ & $\begin{array}{c}29.50 \\
(26.09)\end{array}$ & $\begin{array}{c}28.69 \\
(21.75)\end{array}$ \\
\hline Husband Wage & $\begin{array}{c}56.25 \\
(64.93)\end{array}$ & $\begin{array}{c}56.67 \\
(66.06)\end{array}$ & $\begin{array}{c}50.05 \\
(45.12)\end{array}$ \\
\hline Age & $\begin{array}{l}37.73 \\
(7.68)\end{array}$ & $\begin{array}{l}38.17 \\
(7.63)\end{array}$ & $\begin{array}{l}35.05 \\
(7.43)\end{array}$ \\
\hline Education & $\begin{array}{l}13.66 \\
(2.43)\end{array}$ & $\begin{array}{l}13.69 \\
(2.44)\end{array}$ & $\begin{array}{l}13.46 \\
(2.34)\end{array}$ \\
\hline $\mathrm{N}$ & 2,479 & 2,129 & 350 \\
\hline
\end{tabular}

Note: Wages are in 2005 constant dollars (thousands). $\mathrm{N}$ is the number of women. Standard deviations are in parentheses. 
Table 3: Employment Choice Distribution

\begin{tabular}{|cccccccc|}
\hline Age & $\begin{array}{c}\text { Non- } \\
\text { Employed } \\
(1)\end{array}$ & $\begin{array}{c}\text { Volunteer } \\
\text { Only } \\
(2)\end{array}$ & $\begin{array}{c}\text { Part-time } \\
\text { Only } \\
(3)\end{array}$ & $\begin{array}{c}\text { Full-time } \\
\text { Only } \\
(4)\end{array}$ & $\begin{array}{c}\text { Part-time \& } \\
\text { Volunteer } \\
(5)\end{array}$ & $\begin{array}{c}\text { Full-time \& } \\
\text { Volunteer } \\
(6)\end{array}$ & $\begin{array}{c}\text { Woman- } \\
\text { Years } \\
(7)\end{array}$ \\
\hline & & & & & & & \\
$25-29$ & .117 & .027 & .229 & .409 & .090 & .128 & 743 \\
$30-34$ & .129 & .058 & .213 & .348 & .109 & .142 & 1,252 \\
$35-39$ & .088 & .063 & .210 & .347 & .112 & .180 & 1,264 \\
$40-44$ & .091 & .054 & .195 & .346 & .155 & .160 & 1,396 \\
$45-49$ & .092 & .049 & .175 & .376 & .123 & .185 & 1,338 \\
$50-55$ & .093 & .041 & .174 & .376 & .110 & .206 & 933 \\
& & & & & & & \\
$25-55$ & .101 & .051 & .198 & .363 & .120 & .168 & 6,926 \\
\hline
\end{tabular}

Note: Figures are row percentages. Percentages are computed conditional on non-missing employment choices.

Table 4: Two-Year Employment Transition Matrix

\begin{tabular}{|ccccccc|}
\hline & $\begin{array}{c}\text { Non- } \\
\text { Employed } \\
(1)\end{array}$ & $\begin{array}{c}\text { Volunteer } \\
\text { Only } \\
(2)\end{array}$ & $\begin{array}{c}\text { Part-time } \\
\text { Only } \\
(3)\end{array}$ & $\begin{array}{c}\text { Full-time } \\
\text { Only } \\
(4)\end{array}$ & $\begin{array}{c}\text { Part-time \& } \\
\text { Volunteer } \\
(5)\end{array}$ & $\begin{array}{c}\text { Full-time \& } \\
\text { Volunteer } \\
(6)\end{array}$ \\
\hline $\begin{array}{c}\text { Non- } \\
\text { Employed }\end{array}$ & .496 & .157 & .186 & .082 & .056 & .022 \\
$\begin{array}{c}\text { Volunteer } \\
\text { Only }\end{array}$ & .159 & .439 & .070 & .037 & .229 & .065 \\
$\begin{array}{c}\text { Part-time } \\
\text { Only }\end{array}$ & .097 & .024 & .431 & .266 & .120 & .063 \\
$\begin{array}{c}\text { Full-time } \\
\text { Only }\end{array}$ & .054 & .009 & .146 & .617 & .034 & .140 \\
$\begin{array}{c}\text { Part-time \& } \\
\text { Volunteer }\end{array}$ & .042 & .066 & .198 & .106 & .424 & .164 \\
$\begin{array}{c}\text { Full-time \& } \\
\text { Volunteer }\end{array}$ & .022 & .015 & .075 & .273 & .122 & .492 \\
\hline
\end{tabular}

Note: Figures are row percentages. Percentages are computed conditional on non-missing employment choices. 
Table 5: Reduced-Form Regressions

\begin{tabular}{|c|c|c|c|c|c|c|c|c|}
\hline & Volunteer & Marriage & Birth & $\begin{array}{c}\text { Log } \\
\text { Husband } \\
\text { Wage }\end{array}$ & & Log Acce & ted Wag & \\
\hline & (1) & (2) & $(3)$ & & (5) & (6) & $(7)$ & (8) \\
\hline Constant & -.701 & -1.035 & .337 & 7.965 & 8.990 & 8.988 & 7.646 & 8.029 \\
\hline & $(.168)$ & $(.142)$ & $(.113)$ & $(.379)$ & $(.331)$ & $(.443)$ & $(.419)$ & $(.493)$ \\
\hline $\mathrm{I}(12 \leq \mathrm{Edu}<16)$ & .237 & .097 & .023 & .517 & .664 & .678 & .484 & .563 \\
\hline & $(.021)$ & $(.028)$ & $(.009)$ & $(.063)$ & $(.056)$ & $(.068)$ & $(.063)$ & $(.086)$ \\
\hline $\mathrm{I}(\mathrm{Edu} \geq 16)$ & .418 & .151 & .066 & .863 & 1.117 & 1.139 & .935 & 1.007 \\
\hline & $(.024)$ & $(.029)$ & $(.010)$ & $(.067)$ & $(.059)$ & $(.073)$ & $(.068)$ & $(.091)$ \\
\hline Age & .030 & .076 & -.013 & .089 & -.009 & -.003 & .023 & .008 \\
\hline & $(.009)$ & $(.007)$ & $(.006)$ & $(.019)$ & $(.017)$ & $(.022)$ & $(.020)$ & $(.024)$ \\
\hline Age-squared & -.0004 & -.0008 & .00004 & -.0009 & .0003 & .0002 & -.0001 & .0001 \\
\hline & $(.0001)$ & $(.0001)$ & $(.0001)$ & $(.0002)$ & $(.0002)$ & $(.0003)$ & $(.0002)$ & $(.0003)$ \\
\hline Married & $\begin{array}{c}.040 \\
(.015)\end{array}$ & & $\begin{array}{c}.045 \\
(.004)\end{array}$ & & & & & \\
\hline \#kids & .077 & & .044 & & & & & \\
\hline & $(.012)$ & & $(.005)$ & & & & & \\
\hline \#kids-squared & $\begin{array}{l}-.0095 \\
(.0025)\end{array}$ & & $\begin{array}{l}-.0032 \\
(.0013)\end{array}$ & & & & & \\
\hline Volunteered & & & & & & $\begin{array}{l}-.143 \\
(.034)\end{array}$ & $\begin{array}{l}-.069 \\
(.031)\end{array}$ & $\begin{array}{l}-.038 \\
(.028)\end{array}$ \\
\hline Worked PT & & & & & & & $\begin{array}{c}.681 \\
(.093)\end{array}$ & $\begin{array}{c}.633 \\
(.082)\end{array}$ \\
\hline Worked FT & & & & & & & $\begin{array}{l}1.365 \\
(.090)\end{array}$ & $\begin{array}{c}.959 \\
(.080)\end{array}$ \\
\hline$\rho$ & .371 & .805 & .000 & .645 & & & & .669 \\
\hline $\mathrm{N}$ & 2,479 & 2,479 & 1,988 & 1,894 & 2,305 & 2,032 & 2,032 & 2,032 \\
\hline NT & 6,926 & 12,395 & 8,953 & 4,812 & 5,877 & 3,707 & 3,707 & 3,707 \\
\hline$R^{2}$ & .073 & .024 & .073 & .090 & .098 & .100 & .271 & .245 \\
\hline
\end{tabular}

Note: $\rho$ is the fraction of variance due to the random effect. $\mathrm{N}$ is the number of women. NT is the number of woman-year observations. Column (3) includes only women less than 46 years old. The employment status dummies (Volunteered, Worked PT, and Worked FT) refer to the prior wave (2 years earlier). Robust standard errors are in parentheses. 
Table 6: SML Estimates

\begin{tabular}{|c|c|c|c|c|c|c|c|}
\hline & $\begin{array}{c}\text { Part-time } \\
\text { Wage } \\
\ln \left(w_{a}^{p}\right) \\
(1)\end{array}$ & $\begin{array}{c}\text { Full-time } \\
\text { Wage } \\
\ln \left(w_{a}^{f}\right) \\
(2)\end{array}$ & $\begin{array}{c}\text { Prob } \\
\text { Type } 1 \\
\pi_{1}^{A} \\
(3)\end{array}$ & $\begin{array}{c}\text { Prob } \\
\text { Type } 2 \\
\pi_{2}^{A} \\
(4)\end{array}$ & $\begin{array}{c}\text { Prob } \\
\text { Type } 3 \\
\pi_{3}^{A} \\
(5)\end{array}$ & $\begin{array}{c}\text { Warm } \\
\text { Glow } \\
g \\
(6)\end{array}$ & $\begin{array}{l}\text { Husband } \\
\text { Wage } \\
\ln \left(w_{a}^{h}\right) \\
\quad(7)\end{array}$ \\
\hline Constant & $\begin{array}{l}7.504 \\
(.004)\end{array}$ & $\begin{array}{l}8.398 \\
(.008)\end{array}$ & $\begin{array}{l}-1.078 \\
(.367)\end{array}$ & $\begin{array}{c}.497 \\
(.286)\end{array}$ & $\begin{array}{l}-.133 \\
(.301)\end{array}$ & $\begin{array}{l}-1.407 \\
(.004)\end{array}$ & $\begin{array}{l}8.145 \\
(.006)\end{array}$ \\
\hline$E_{1}$ & $\begin{array}{c}.427 \\
(.002)\end{array}$ & $\begin{array}{l}.486 \\
(.002)\end{array}$ & $\begin{array}{l}-.268 \\
(.367)\end{array}$ & $\begin{array}{l}-.071 \\
(.273)\end{array}$ & $\begin{array}{l}.159 \\
(.277)\end{array}$ & $\begin{array}{l}2.809 \\
(.007)\end{array}$ & $\begin{array}{l}.488 \\
(.002)\end{array}$ \\
\hline$E_{2}$ & $\begin{array}{l}.768 \\
(.004)\end{array}$ & $\begin{array}{l}1.010 \\
(.003)\end{array}$ & $\begin{array}{l}.269 \\
(.380)\end{array}$ & $\begin{array}{l}.006 \\
(.289)\end{array}$ & $\begin{array}{l}-.236 \\
(.302)\end{array}$ & $\begin{array}{l}3.417 \\
(.010)\end{array}$ & $\begin{array}{c}.842 \\
(.003)\end{array}$ \\
\hline$A_{1}$ & $\begin{array}{r}-1.093 \\
(.005)\end{array}$ & $\begin{array}{r}-1.624 \\
(.027)\end{array}$ & & & & & \\
\hline$A_{2}$ & $\begin{array}{c}.601 \\
(.004)\end{array}$ & $\begin{array}{l}.664 \\
(.003)\end{array}$ & & & & & \\
\hline$A_{3}$ & $\begin{array}{l}1.185 \\
(.018)\end{array}$ & $\begin{array}{l}1.265 \\
(.006)\end{array}$ & & & & & \\
\hline$x_{a}^{v}$ & $\begin{array}{c}.083 \\
(.0003)\end{array}$ & $\begin{array}{c}.024 \\
(.0001)\end{array}$ & & & & & \\
\hline $\begin{array}{l}x_{a}^{p} \\
\left(x_{a}^{p}\right)^{2}\end{array}$ & $\begin{array}{c}.163 \\
(.0007) \\
-.010 \\
(.00004)\end{array}$ & $\begin{array}{c}.029 \\
(.0002)\end{array}$ & & & & & \\
\hline $\begin{array}{l}x_{a}^{f} \\
\left(x_{a}^{f}\right)^{2}\end{array}$ & $\begin{array}{c}-.007 \\
(.00004)\end{array}$ & $\begin{array}{c}.031 \\
(.0001) \\
-.0008 \\
(.000004)\end{array}$ & & & & & \\
\hline$a^{2}$ & & & $\begin{array}{c}.032 \\
(.013)\end{array}$ & $\begin{array}{c}.005 \\
(.010)\end{array}$ & $\begin{array}{c}.003 \\
(.010)\end{array}$ & $\begin{array}{c}-.0003 \\
(.00003)\end{array}$ & $\begin{array}{c}.081 \\
(.0001) \\
-.0009 \\
(.000002)\end{array}$ \\
\hline $\begin{array}{l}n_{a}^{1,6} \\
n_{a}^{7,18}\end{array}$ & & & & & & $\begin{array}{l}-.924 \\
(.011) \\
2.809 \\
(.007)\end{array}$ & \\
\hline$\sigma_{\mu}$ & & & & & & & $\begin{array}{c}.362 \\
(.001) \\
.414 \\
(.002)\end{array}$ \\
\hline
\end{tabular}

Note: In Columns (3)-(5), $a$ is birth cohort $C$. Asymptotic standard errors are in parentheses. 
Table 7: SML Estimates (cont'd)

\begin{tabular}{|c|c|c|c|c|c|}
\hline & $\begin{array}{c}\text { Marriage } \\
\text { Utility } \\
\psi^{m} \\
(1)\end{array}$ & $\begin{array}{c}\text { Child } \\
\text { Utility } \\
\psi^{n} \\
(2)\end{array}$ & $\begin{array}{c}\text { Costs of } \\
\text { Children } \\
c_{k} \\
(3)\end{array}$ & $\begin{array}{c}\text { Approx } \\
\operatorname{Emax} \\
\hat{E}\left(V_{a+2}\right) \\
\quad(4)\end{array}$ & $\begin{array}{c}\text { Non-Response } \\
\text { Probability } \\
\pi^{n r} \\
(5)\end{array}$ \\
\hline Constant & & & & & $\begin{array}{c}-1.114 \\
(.176)\end{array}$ \\
\hline$x_{a}^{v}$ & & & & $\begin{array}{c}.071 \\
(.0009)\end{array}$ & \\
\hline$x_{a}^{p}$ & & & & $\begin{array}{l}.170 \\
(.002)\end{array}$ & \\
\hline$x_{a}^{f}$ & & & & $\begin{array}{l}.713 \\
(.006)\end{array}$ & \\
\hline$x_{a}^{m}$ & $\begin{array}{l}-.051 \\
(.001)\end{array}$ & & & $\begin{array}{l}-.006 \\
(.0004)\end{array}$ & \\
\hline$n_{a}$ & & $\begin{array}{l}15.318 \\
(.097)\end{array}$ & & $\begin{array}{l}1.381 \\
(.014)\end{array}$ & \\
\hline$n_{a}^{2}$ & & $\begin{array}{c}-3.276 \\
(.033)\end{array}$ & & & \\
\hline$m_{a} n_{a}$ & & $\begin{array}{l}13.666 \\
(.096)\end{array}$ & & & \\
\hline$m_{a} n_{a}^{2}$ & & $\begin{array}{r}-2.575 \\
(.028)\end{array}$ & & & \\
\hline$b_{a}$ & & & $\begin{array}{c}29,071 \\
(86.5)\end{array}$ & & \\
\hline Non-emp & & & $\begin{array}{c}19,913 \\
(41.5)\end{array}$ & & \\
\hline Vol & & & $\begin{array}{l}5,106 \\
(23.3)\end{array}$ & & $\begin{array}{l}.774 \\
(.171)\end{array}$ \\
\hline PT & & & $\begin{array}{c}21,882 \\
(42.4)\end{array}$ & & $\begin{array}{l}-.917 \\
(.272)\end{array}$ \\
\hline FT & & & $\begin{array}{c}26,819 \\
(64.8)\end{array}$ & & $\begin{array}{l}-.182 \\
(.169)\end{array}$ \\
\hline$m_{a}$ & & & & & $\begin{array}{r}-1.606 \\
(.148)\end{array}$ \\
\hline$n_{a}^{1,6}$ & & & & & $\begin{array}{c}.284 \\
(.177)\end{array}$ \\
\hline$n_{a}^{7,18}$ & & & & & $\begin{array}{l}-1.412 \\
(.324)\end{array}$ \\
\hline$l_{2003}$ & & & & & $\begin{array}{l}-.042 \\
(.004)\end{array}$ \\
\hline$\alpha_{c}$ & & & $\begin{array}{l}1.446 \\
(.006)\end{array}$ & & \\
\hline
\end{tabular}

Note: Asymptotic standard errors are in parentheses. 
Table 8: SML Estimates (cont'd)

\begin{tabular}{|c|c|c|c|c|c|c|c|c|}
\hline CRRA & & $\begin{array}{l}\text { b } \\
\text { Prob }\end{array}$ & \multicolumn{4}{|c|}{ Elements } & $\begin{array}{l}\text { Income } \\
\text { Sharing }\end{array}$ & $\begin{array}{l}\text { Marriage } \\
\text { Offer Prob }\end{array}$ \\
\hline $1-\lambda$ & $\pi_{1}^{f}$ & $\pi_{3}^{f}$ & $l_{21}$ & $l_{31}$ & $l_{32}$ & $l_{43}$ & $\tau^{1}$ & $\pi^{m}$ \\
\hline .273 & .930 & .950 & .058 & -.113 & -.090 & .012 & .551 & .089 \\
\hline$(.0007)$ & $(.004)$ & $(.014)$ & $(.001)$ & $(.0009)$ & $(.0009)$ & $(.0002)$ & $(.001)$ & $(.0002)$ \\
\hline \multirow{2}{*}{\multicolumn{3}{|c|}{$\begin{array}{c}\text { Unobserved Consumption an } \\
\text { Disutility of Work Effort }\end{array}$}} & & \multirow{2}{*}{\multicolumn{5}{|c|}{ Error Variances }} \\
\hline & & & & & & & & \\
\hline$b$ & $\mu_{2}$ & $\mu_{3}$ & & $\sigma_{\varepsilon_{a}^{u}}^{u}$ & $\sigma_{\varepsilon_{a}^{g}}$ & $\sigma_{\varepsilon_{a}^{p}}$ & $\sigma_{\varepsilon_{a}^{f}}$ & $\sigma_{\varepsilon_{a}^{h}}$ \\
\hline 2,064 & .978 & .981 & & 1.416 & 1.853 & .036 & .030 & .042 \\
\hline $\begin{array}{c}(7.1) \\
\mu_{4}\end{array}$ & $(.0008)$ & $(.0006)$ & & $(.007)$ & $\begin{array}{l}(.008) \\
\sigma_{n e, 3}\end{array}$ & $\begin{array}{c}(.0005) \\
\sigma_{p_{e .4}}\end{array}$ & $\begin{array}{c}(.0005) \\
\sigma_{n h 0}\end{array}$ & $\begin{array}{c}(.0003) \\
\sigma_{n^{h, 1}}\end{array}$ \\
\hline $\begin{array}{l}\mu_{4} \\
.915\end{array}$ & $\begin{array}{c}\mu_{5} \\
.960\end{array}$ & $\begin{array}{c}\mu_{6} \\
.879\end{array}$ & & $\begin{array}{c}O \eta^{e, 1} \\
8.095\end{array}$ & $\begin{array}{r}O_{\eta^{e, 3}} \\
1.026\end{array}$ & $\begin{array}{l}\eta_{\eta^{e, 4}} \\
.453\end{array}$ & $\begin{array}{l}\sigma \eta^{h, 0} \\
9.949\end{array}$ & $\begin{array}{l}\sigma_{\eta^{h, 1}} \\
.658\end{array}$ \\
\hline$(.0004)$ & $(.0006)$ & $(.0003)$ & & $(2.052)$ & $(.018)$ & $(.004)$ & $(3.774)$ & $(.004)$ \\
\hline \multicolumn{9}{|c|}{ Classification Error } \\
\hline \multirow{2}{*}{\multicolumn{6}{|c|}{$\begin{array}{l}\text { Employment } \\
\pi_{i k}^{e}\end{array}$}} & & \multirow{2}{*}{\multicolumn{2}{|c|}{$\begin{array}{l}\text { Marriage } \\
\pi_{j k}^{m}\end{array}$}} \\
\hline & & & & & & & & \\
\hline .9950 & .0009 & .0009 & .0009 & .0009 & . 0009 & & .9151 & .0849 \\
\hline .0006 & .7899 & '0007. & (0007. & .2072 & (0007. & & .0356 & .9644 \\
\hline .0009 & .0009 & .9955 & . 0009 & . 0009 & .0009 & & \multicolumn{2}{|c|}{$\begin{array}{l}\text { Birth } \\
\pi^{b}\end{array}$} \\
\hline .0007 & .0007 & 2072 & .7899 & .0007 & .0007 & & & $\pi_{j k}^{b}$ \\
\hline .0007 & .0007 & .0007 & .0007 & .7899 & .2072 & & .9820 & .0180 \\
\hline .0007 & .0007 & .0007 & .0007 & 1780 & .8191 & & .0180 & .9820 \\
\hline
\end{tabular}

Note: Asymptotic standard errors are in parentheses. Standard errors for classification rates are available upon request. 
Table 9: Actual and Predicted Employment Choice Distribution

\begin{tabular}{|ccccccc|}
\hline & $\begin{array}{c}\text { Non- } \\
\text { Employed } \\
(1)\end{array}$ & $\begin{array}{c}\text { Volunteer } \\
\text { Only } \\
(2)\end{array}$ & $\begin{array}{c}\text { Part-time } \\
\text { Only } \\
(3)\end{array}$ & $\begin{array}{c}\text { Full-time } \\
\text { Only } \\
(4)\end{array}$ & $\begin{array}{c}\text { Part-time \& } \\
\text { Volunteer } \\
(5)\end{array}$ & $\begin{array}{c}\text { Full-time \& } \\
\text { Volunteer } \\
(6)\end{array}$ \\
\hline \multirow{2}{*}{$25-29$} & .117 & .027 & .229 & .409 & .090 & .128 \\
& $(.098)$ & $(.037)$ & $(.175)$ & $(.452)$ & $(.080)$ & $(.160)$ \\
$30-34$ & .129 & .058 & .213 & .348 & .109 & .142 \\
& $(.112)$ & $(.031)$ & $(.190)$ & $.415)$ & $(.098)$ & $(.154)$ \\
$35-39$ & .088 & .063 & .210 & .347 & .112 & .180 \\
& $(.094)$ & $(.034)$ & $(.194)$ & $(.342)$ & $(.138)$ & $(.197)$ \\
$40-44$ & .091 & .054 & .195 & .346 & .155 & .160 \\
& $(.075)$ & $(.034)$ & $(.174)$ & $(.313)$ & $(.176)$ & $(.229)$ \\
$45-49$ & .092 & .049 & .175 & .376 & .123 & .185 \\
& $(.087)$ & $(.032)$ & $(.204)$ & $. .318)$ & $(.147)$ & $(.211)$ \\
$50-55$ & .093 & .041 & .174 & .376 & .110 & .206 \\
& $(.073)$ & $(.035)$ & $(.205)$ & $(.324)$ & $(.156)$ & $(.207)$ \\
& & & & & & \\
$25-55$ & .101 & .051 & .198 & .363 & .120 & .168 \\
& $(.090)$ & $(.034)$ & $(.190)$ & $(.356)$ & $(.135)$ & $(.195)$ \\
\hline
\end{tabular}

Note: Figures are row percentages. Predicted values are in parentheses. 
Table 10: Actual and Predicted Two-Year Employment Transition Matrix

\begin{tabular}{|c|c|c|c|c|c|c|}
\hline \multirow[b]{2}{*}{$a$} & \multicolumn{6}{|c|}{$a+2$} \\
\hline & $\begin{array}{c}\text { Non- } \\
\text { Employed } \\
(1)\end{array}$ & $\begin{array}{c}\text { Volunteer } \\
\text { Only } \\
(2)\end{array}$ & $\begin{array}{c}\text { Part-time } \\
\text { Only } \\
(3)\end{array}$ & $\begin{array}{c}\text { Full-time } \\
\text { Only } \\
(4)\end{array}$ & $\begin{array}{l}\text { Part-time \& } \\
\text { Volunteer } \\
(5)\end{array}$ & $\begin{array}{c}\text { Full-time \& } \\
\text { Volunteer } \\
(6)\end{array}$ \\
\hline $\begin{array}{c}\text { Non- } \\
\text { Employed }\end{array}$ & $\begin{array}{l}.496 \\
(.511)\end{array}$ & $\begin{array}{c}.157 \\
(.132)\end{array}$ & $\begin{array}{l}.186 \\
(.191)\end{array}$ & $\begin{array}{c}.082 \\
(.062)\end{array}$ & $\begin{array}{c}.056 \\
(.077)\end{array}$ & $\begin{array}{c}.022 \\
(.026)\end{array}$ \\
\hline $\begin{array}{c}\text { Volunteer } \\
\text { Only }\end{array}$ & $\begin{array}{l}.159 \\
(.281)\end{array}$ & $\begin{array}{c}.439 \\
(.370)\end{array}$ & $\begin{array}{c}.070 \\
(.094)\end{array}$ & $\begin{array}{c}.037 \\
(.014)\end{array}$ & $\begin{array}{c}.229 \\
(.200)\end{array}$ & $\begin{array}{c}.065 \\
(.040)\end{array}$ \\
\hline $\begin{array}{l}\text { Part-time } \\
\text { Only }\end{array}$ & $\begin{array}{l}.097 \\
(.070)\end{array}$ & $\begin{array}{l}.024 \\
(.013)\end{array}$ & $\begin{array}{l}.431 \\
(.310)\end{array}$ & $\begin{array}{l}.266 \\
(.318)\end{array}$ & $\begin{array}{l}.120 \\
(.149)\end{array}$ & $\begin{array}{c}.063 \\
(.140)\end{array}$ \\
\hline $\begin{array}{c}\text { Full-time } \\
\text { Only }\end{array}$ & $\begin{array}{l}.054 \\
(.022)\end{array}$ & $\begin{array}{c}.009 \\
(.003)\end{array}$ & $\begin{array}{l}.146 \\
(.163)\end{array}$ & $\begin{array}{c}.617 \\
(.568)\end{array}$ & $\begin{array}{c}.034 \\
(.053)\end{array}$ & $\begin{array}{l}.140 \\
(.191)\end{array}$ \\
\hline $\begin{array}{c}\text { Part-time \& } \\
\text { Volunteer }\end{array}$ & $\begin{array}{c}.042 \\
(.052)\end{array}$ & $\begin{array}{c}.066 \\
(.029)\end{array}$ & $\begin{array}{l}.198 \\
(.199)\end{array}$ & $\begin{array}{l}.106 \\
(.139)\end{array}$ & $\begin{array}{c}.424 \\
(.366)\end{array}$ & $\begin{array}{c}.164 \\
(.215)\end{array}$ \\
\hline $\begin{array}{l}\text { Full-time \& } \\
\text { Volunteer }\end{array}$ & $\begin{array}{c}.022 \\
(.026)\end{array}$ & $\begin{array}{l}.015 \\
(.002)\end{array}$ & $\begin{array}{c}.075 \\
(.138)\end{array}$ & $\begin{array}{c}.273 \\
(.324)\end{array}$ & $\begin{array}{c}.122 \\
(.148)\end{array}$ & $\begin{array}{c}.492 \\
(.362)\end{array}$ \\
\hline
\end{tabular}

Note: Figures are row percentages. Predicted values are in parentheses.

Table 11: Actual and Predicted Marriage, Birth, Wages and Experience

\begin{tabular}{|c|c|c|c|c|c|c|c|}
\hline Married & Birth & $\begin{array}{l}\text { Birth } \\
\text { Single }\end{array}$ & $\begin{array}{c}\text { Birth } \\
\text { Married }\end{array}$ & $\begin{array}{l}\text { Accepted } \\
\text { Wage }\end{array}$ & $\begin{array}{c}\text { Accepted } \\
\text { Part-time } \\
\text { Wage }\end{array}$ & $\begin{array}{c}\text { Accepted } \\
\text { Full-time } \\
\text { Wage }\end{array}$ & $\begin{array}{c}\text { Accepted } \\
\text { Husband } \\
\text { Wage }\end{array}$ \\
\hline $\begin{array}{l}.748 \\
(.710)\end{array}$ & $\begin{array}{l}.060 \\
(.056)\end{array}$ & $\begin{array}{l}.023 \\
(.024)\end{array}$ & $\begin{array}{c}.074 \\
(.073)\end{array}$ & $\begin{array}{c}29,432 \\
(30,820)\end{array}$ & $\begin{array}{c}17,710 \\
(20,141)\end{array}$ & $\begin{array}{c}36,446 \\
(34,234)\end{array}$ & $\begin{array}{c}56,248 \\
(55,939)\end{array}$ \\
\hline $\begin{array}{c}\mathrm{a} \\
\text { Single } \\
\text { Married }\end{array}$ & $\begin{array}{c}\text { Marria } \\
\\
\text { Single } \\
.799 \\
(.731) \\
.029 \\
(.069)\end{array}$ & $\begin{array}{c}\text { e/Divorce } \\
+2 \\
\text { Married } \\
.201 \\
(.269) \\
.971 \\
(.931)\end{array}$ & & $\begin{array}{c}\text { Volv } \\
0 \\
.487 \\
(.263) \\
3 \\
.140 \\
(.171)\end{array}$ & $\begin{array}{c}\text { iteer Exper } \\
1 \\
.221 \\
(.184) \\
4 \\
0 \\
(.120)\end{array}$ & $\begin{array}{c}\text { ience } \\
2 \\
.152 \\
(.178) \\
5 \\
0 \\
(.084)\end{array}$ & \\
\hline
\end{tabular}

Note: Birth percentages are for $a \leq 45$. Predicted values are in parentheses. 
Table 12: Reduced-Form Regressions (Simulated Data)

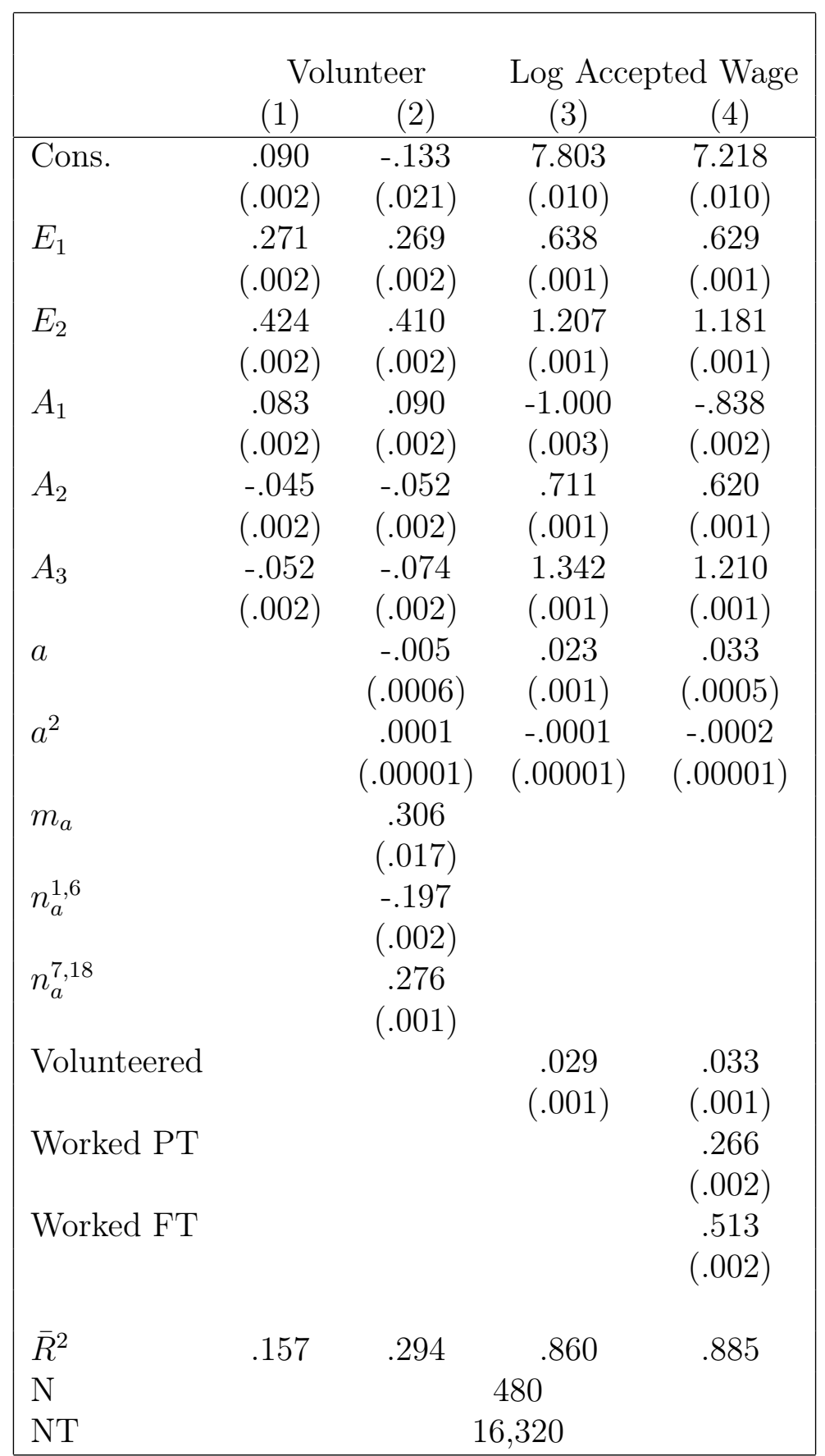

Note: N is the number of simulated women. NT is the number of simulated woman-year observations. Robust standard errors are in parentheses. 
Table 13: Relative Importance and Tax Policy

\begin{tabular}{|c|c|c|c|c|}
\hline & $\begin{array}{l}\text { No Non-Economic } \\
\text { or Economic } \\
\text { Returns } \\
(1)\end{array}$ & $\begin{array}{c}\text { Only } \\
\text { Non-economic } \\
\text { Returns } \\
(2)\end{array}$ & $\begin{array}{c}\text { Economic and } \\
\text { Non-economic } \\
\text { Returns } \\
(3)\end{array}$ & $\begin{array}{c}\text { Tax } \\
\text { Credit } \\
(4)\end{array}$ \\
\hline Volunteer (Total) & .0000 & .2775 & .3030 & .4108 \\
\hline Non-employed & .2641 & 1861 & .1362 & .1104 \\
\hline Volunteer Only & .0000 & .0968 & .0410 & .0509 \\
\hline Part-time Only & .0714 & .0403 & .0801 & .0716 \\
\hline Full-time Only & .6645 & 4962 & .4807 & .4072 \\
\hline Part-time \& Volunteer & .0000 & 0169 & .0778 & 1396 \\
\hline Full-time \& Volunteer & .0000 & 1638 & 1842 & .2203 \\
\hline Married & .662 & .660 & .647 & .654 \\
\hline Total Fertility & .427 & .425 & .453 & .466 \\
\hline Non-labor Income & 40,367 & 40,401 & 40,847 & 40,861 \\
\hline Accepted Wage & 21,589 & 22,078 & 24,194 & 25,272 \\
\hline Lifetime Earnings & 247,105 & 246,303 & 288,620 & 299,376 \\
\hline Lifetime Utility & 1852.46 & 1860.64 & 1898.70 & 1923.78 \\
\hline Lifetime Benefit & & & & 10,756 \\
\hline Lifetime Subsidy & & & & 29,500 \\
\hline Net Cost & & & & 18,744 \\
\hline
\end{tabular}

Note: Lifetime figures are discounted between the ages of 22 and 55. Lifetime earnings includes zeros. 